\title{
Vertebrate Taphonomy and Diagenesis: Implications of Structural and Compositional Alterations of Phosphate Biominerals
}

\author{
Yannicke Dauphin (D)
}

check for updates

Citation: Dauphin, Y. Vertebrate Taphonomy and Diagenesis: Implications of Structural and Compositional Alterations of Phosphate Biominerals. Minerals 2022, 12, 180. https://doi.org/ $10.3390 / \min 12020180$

Academic Editor: Yul Roh

Received: 11 December 2021

Accepted: 28 January 2022

Published: 30 January 2022

Publisher's Note: MDPI stays neutral with regard to jurisdictional claims in published maps and institutional affiliations.

Copyright: (C) 2022 by the author. Licensee MDPI, Basel, Switzerland. This article is an open access article distributed under the terms and conditions of the Creative Commons Attribution (CC BY) license (https:// creativecommons.org/licenses/by/ $4.0 /)$.
Institut de Systématique, Evolution, Biodiversité (ISYEB), UMR 7205 CNRS Muséum National d'Histoire Naturelle, Sorbonne-Université, EPHE, 75005 Paris, France; yannicke.dauphin@sorbonne-universite.fr

\begin{abstract}
Biominerals are recorders of evolution and palaeoenvironments. Predation is one of the most frequent modes leading to the concentration of small vertebrates in fossil assemblages. Consumption by predators produces damages on bones and teeth from prey species, and one of the greatest challenges to taphonomists is differentiating original biological and secondary, geologically altered attributes of fossils. Excellent morphological preservation is often used to assume that the structure and composition of fossils are not modified. Nevertheless, during predation and fossilization, both the physical structure and chemical composition of enamel, dentine and bone are altered, the degree and extent of which varies from site to site, depending on the nature of the burial environment. A relationship between the surficial alterations and the compositional changes which take place during fossilization has yet to be established. Herein, I present a review of old and recent taphonomic studies that collectively reveal the wide diversity of microstructural and chemical changes that typically take place during fossilization of vertebrate remains, including common taphonomic biases and the challenges inherent to reconstructing the history of vertebrate fossil assemblages.
\end{abstract}

Keywords: taphonomy; bone; teeth; microstructure; composition; diagenesis

\section{Introduction}

Studies of present-day biodiversity are done using direct observations of organisms or traces of activity such as imprints, moulted skin, feathers ... or droppings. For organisms with an inner skeleton, bone and teeth are also used. To estimate the biodiversity evolution through geological times, hard parts of organisms are the dominant tools. Unfortunately, these remains, fossils, have undergone modifications, sometimes difficult to detect. According to Bengston [1] " . . it is not unlikely that most of the short-term diversity changes reported from the fossil record are in fact a function of differential preservation in the rock record ...". So, reconstructions of past life, environment and biodiversity are strongly dependent on our knowledge of the origins of modifications induced from death of the organisms until the discovery of the sample.

The transition between living organisms and fossils, called fossilization by palaeontologists, is a rare event. The process is also called diagenesis or taphonomy. In fossilization, diagenesis and taphonomy are not perfect synonyms, but they both express the modifications of an object through its historical or geological history. "Diagenesis" was used by Von Gumbel [2] for a post-sedimentary, non-metamorphic transformation of sediments into a different sedimentary rock at low temperatures and pressures. Taphonomy was defined as "the laws of embedding" [3], but most studies involve the cause of the death of the organism. Whatever the term, these processes induce changes in the fossil samples.

To decipher and to identify the structural and chemical alterations in fossils, a necessary step is the knowledge of the structure and composition of living organisms. Unfortunately, fossils and present-day taxa differ: all living organisms do not exist in geological times, and reciprocally, fossils do not always have present-day equivalents. Nevertheless, 
detecting and identifying the cause(s) of modifications is the only way to reduce the bias induced in reconstructions of ancient times.

Fossilization depends on two main categories of factors: intrinsic and extrinsic factors. Among intrinsic features are the size, shape, composition, structure and mineralogy of the sample. Extrinsic factors are environment (predation, sediment, temperature, water, etc.) and geological age and history of the sample.

Ca-phosphates, Ca-carbonates and silica are the dominant biominerals in skeletons and shells. Biogenic Ca-phosphates and Ca-carbonates are mainly crystalline, whereas biogenic silica is always amorphous. Structure, microstructure and composition of the skeletons are characteristic of a unique species [4]. Thus, the combination of the intrinsic biological characteristics and of the extrinsic geological factors offers a very wide range of possible cases, too large for every case to be described. Here, the selected examples come from Ca-phosphates of vertebrate animals, most of them being terrestrial. Given the diversity of the multiple factors involved in the fossilization processes, only some questions, problems and techniques are addressed.

\section{Milestones: From Death to Discovery}

In general, a long period of time passes between the death of an organism and its discovery as a fossil. Major steps in the fossilization process are: (1) death, (2) the time between death and burial and (3) burial in the soil and sediment.

\subsection{Death}

It is often believed that animals die because they are old. However, the main cause of death of vertebrate animals in the wild is predation. Among vertebrates, aquatic predators such as placoderms are known as early as the Silurian period [5]. Predators and scavengers are equipped with strong and large beaks, teeth or claws used to capture, to maintain, to kill, to dismantle and to eat the prey. Bite traces and claw marks are therefore visible on present-day bones (Figure 1a,b). It is sometimes possible to identify the predator from the shape and size of the pit due to the tooth because predators are often highly specialized in their diet. Nevertheless, most often tooth marks of carnivorous mammals are not discriminant [6]. Large bones are broken to be ingested, and/or to extract the bone marrow. Similarly, crushing bones is not an innocuous act: bones are mineralized, and they scratch the surface of the teeth of the predator [7]. Tooth marks, also called bite marks, visible in fossil bones are considered as forms of ichnofossils.

\subsection{Post Mortem Alterations}

For animals killed by predators, the first post mortem alterations are due to the digestion. Mechanical and chemical processes exist, although they are different in reptiles, birds and mammals. Bones of the prey are broken by teeth or gizzard of the predator, and then bones and teeth are etched by the digestive juices. When bones and teeth are not fully digested, they are rejected in regurgitation pellets by bird raptors or in faeces by carnivorous mammals. Regurgitation pellets and faeces contain residual digestive juices and bacteria, so that the alterations are not stopped. They can stay at the surface for years before being buried or dissociated; they are exposed to weathering, trampling and soil and sediment interaction (compaction, concretion). Such modifications may be similar to or hide the digestion traces, so it is often difficult to identify the origin of the alterations. Moreover, they are not exclusive (see: Section 3. Predation, digestion or diagenesis?).

\subsubsection{Surficial Alterations}

Fractures are not the only alteration occurring after the death. Surfaces of bones are affected by desquamation, showing successive layers (Figure 1c). The preservation of the overall morphology is usually associated with both secondary deposits and small broken protuberances (Figure 1d). Tooth enamel, the hardest biogenic phosphatic tissue, is not exempt of alterations. In rodents (Figure 1e) or large mammals (Figure 1f), the outer layer 
can be more or less eroded, so that the structural arrangement of the prisms of the inner layer becomes visible. On the contrary, the tooth surface is sometimes hidden by secondary deposits, the origin of which is usually unknown (Figure 1g-i). Aspects of these deposits greatly differ, and aligned rounded granules suggest a bacterial origin (Figure $1 \mathrm{~h}$ ). The acicular crystallites of the prisms of a rodent enamel are revealed in the broken part of the fossil (Figure 1i).
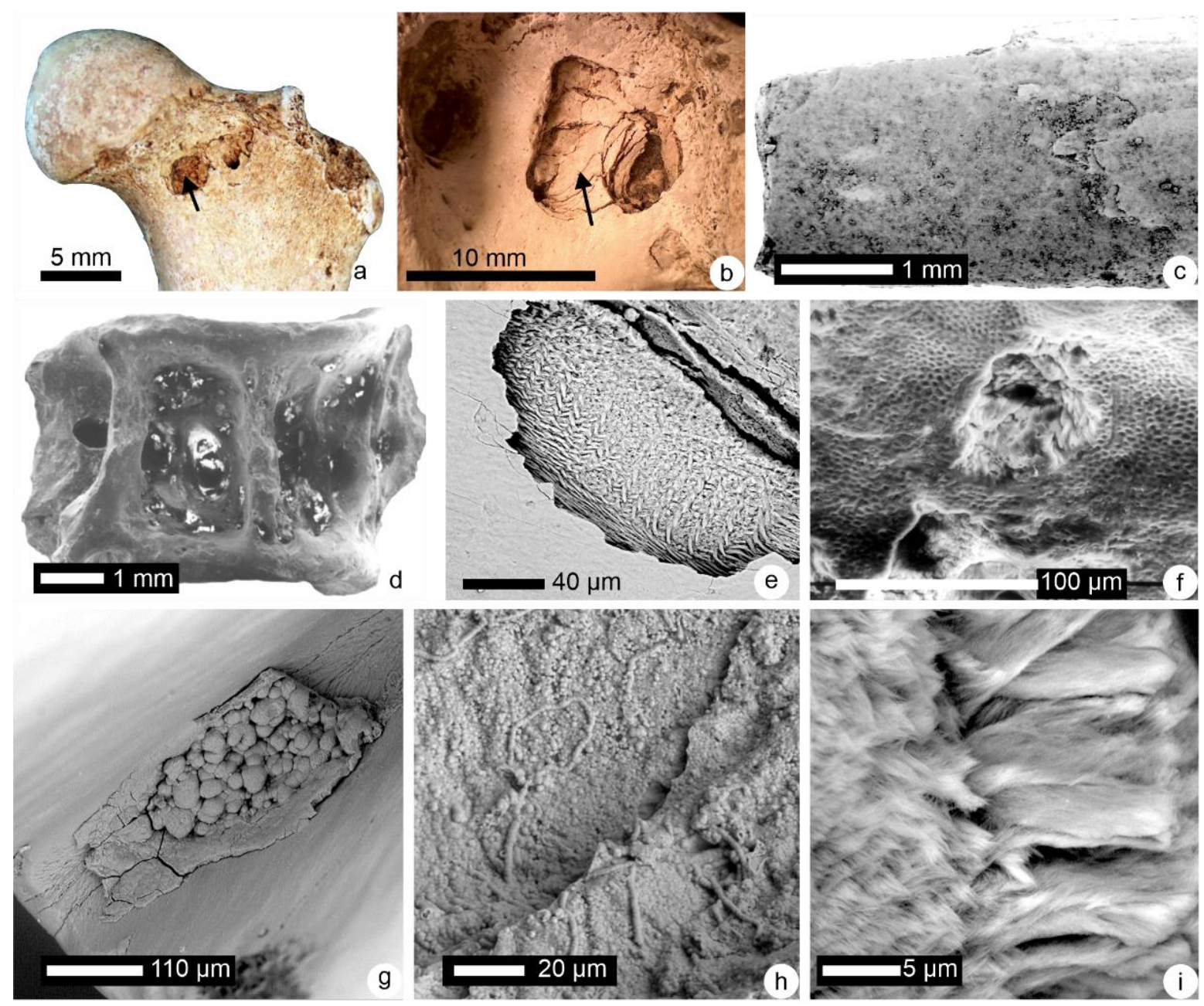

Figure 1. Surficial alterations of bones and teeth. (a,b) Hyena tooth marks (arrows) on a modern striped hyena femur (Djibouti); picture J.B. Fourvel (J. Jaures, Toulouse University, Toulouse, France). (c) Desquamation on a broken fish bone (Malawi, Plio-pleistocene); picture C. Denys (MNHN). (d) Despite a light cleaning, secondary deposits are visible, as well as broken zones in the fish vertebra (Malawi, Plio-pleistocene). (e) Cupule showing the microstructural arrangement of the prismatic inner layer (E) in a fossil rodent tooth (Morocco, Neolithic-Middle Palaeolithic). (f) Cupules (arrows) and eroded enamel outer layer in a tooth of a large mammal (Malawi, Plio-pleistocene). (g) Post mortem secondary deposits in a groove of the surface of a rodent molar (Morocco, NeolithicMiddle Palaeolithic). (h) Rounded granules of uncertain origin (bacteria?) on the dentine of a molar of a large mammal (Moeritherium, Eocene, Algeria). (i) Enamel microstructure is visible in a broken rodent incisor (Morocco, Neolithic-Middle Palaeolithic).

The study of the fractures and surficial alteration is the classical taphonomic analysis [8-10]. As shown by Figure 1, the aspects resulting from these alterations are diverse. An attempt to illustrate the large variation in the taphonomic modifications on bones and teeth has been done [11]. Although the authors compare the results of experimental etchings from diverse factors on the surfaces of present-day bones and teeth with the aspects of fossil 
samples, it is still difficult to identify the changes due to predation and digestion and those due to geological history (burial included). Similar results have been observed for mammal and reptile teeth [12].

Because a fossil is always unique, non-destructive analyses are usually preferred. Colour is rarely studied, although in some taxa (Conodonts), a "conodont alteration index" has been established to estimate the degree of diagenetic changes [13]. When the colour of the external surface of bones or teeth is described, it is a visual identification without any measurement $[14,15]$. Some attempts have been done to link the colour and the chemical composition [16,17]. There is a general agreement that black spots are manganese, but chemical analyses are not done in most cases. Colour perception is variable and nonobjective because of individual variations in human eyes. Nevertheless, colour can be measured through spectrophotometers [18]. Such analyses are non-destructive, so that they are used on rare samples. A present-day bone seems to be white, but the profile in the range of the visible wavelengths shows an increase in the red colour (Figure 2a, Rattus): probably remains of haemoglobin. Three bones of the same site are clearly different, whereas two bones from Quercy, France, are similar (Figure 2a) [19]. The comparison of the colour of the embedding sediment and the surface of the bones show that the slopes of the sediment and the insoluble organic matrix extracted from the bone are similar, but the sediment is darker than the organic matrix (Figure $2 b$ ). The colours of the surface and of the organic matrix are almost identical, both materials being less coloured than humic acids. In this site, the colour seems to be of organic origin. There is a paucity of data concerning the colour, so an index has not yet been established.
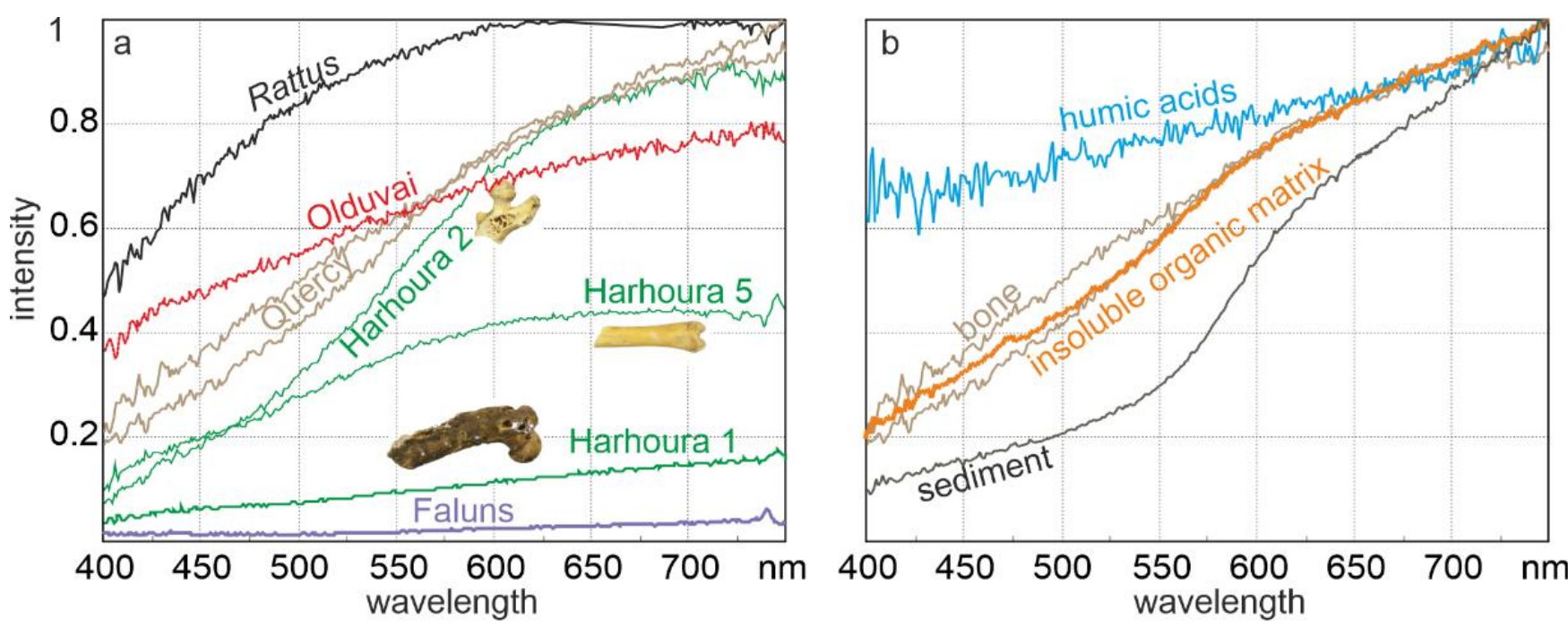

Figure 2. (a) Colour profiles of the outer surface of modern and fossil bones in the visible light range. (b) Comparison of the colour profiles of fossil bones, their organic components, embedding sediment, and commercial humic acids.

\subsubsection{Histological-Structural Modifications}

Analysing the micro- and nanostructural changes is one way to obtain a better understanding of the fossilization mechanisms. These changes are observable at the micron scale using thin sections and electron microscope images [20-22]. Most scanning electron microscope (SEM) images are made using secondary electrons, but back-scattered electron (BSE) mode is sensitive to the atomic number of chemical elements. The mineral components of bone and teeth are rich in "high" atomic number elements (e.g., P, Ca, $\mathrm{Sr} . .$. ), whereas the organic matrix is poor in such elements. Thus, the organic zones are dark; and the mineral zones are bright [23]; attempts have been made to quantify the alterations [24]. Transmission electron microscopes (TEM) are used to decipher the nano(or ultra-) structure of the tissues. Very thin sections of these hard tissues were difficult 
to obtain. Now, technical progress has made it easier to obtain thin sections. Moreover, there is an overlap between the spatial resolution and magnifications of SEM, TEM, and atomic force microscopes (AFM) [25]. When bone is pervaded by nerves and blood vessels in inter-connected canals, micro computed tomography $(\mu \mathrm{CT})$ allows us to observe in $3 \mathrm{D}$ the changes in diameter of these canals, as well as their secondary fillings [26].

After some years buried in a soil, a bone becomes ochre-coloured, but when the secondary fillings are removed, the structure is not modified at the micron scale (Figure 3a). However, the structure of a metapodial from a fossil horse (13th century) is not recognizable (Figure 3b). Digestion by birds of prey does not always lead to strong alterations (Figure 3c). Using surficial damages, Andrews [27] has established five categories of predators. Unfortunately, there is no clear correspondence with the categories based on the $\mathrm{pH}$ and water quantities in the regurgitation pellets [28]. In both papers, the microstructure, or histology of the bone is not taken into account. The quality of the structural preservation of fossil samples is highly variable and not related to the taxa (Figure $3 \mathrm{~d}-1$ ). The histology is well preserved in some cases (Figure 3d,h) but is not identifiable in other samples (Figure 3f,g). Based on current knowledge, there is no correlation between the geological age of the site and the quality of the structural preservation. Filaments, often said to be fungi, are not rare (Figure 3f), as well as small secondary crystals (Figure 3g) [29]. Despite the fact that fish bones are usually thin, not strongly mineralized and fragile, their inner structure can be well preserved and crystallites are still visible (Figure $3 \mathrm{~h}$ ). On the contrary, the original microstructure of large fossil mammal bones can be destroyed (Figure 3i,j). Two different aspects exist in a given bone: the surface of bone cavities is partly covered with secondary mineral crystals, but beneath the surface, the bone structure is still identifiable (Figure 3k,l). The preservation of the morphology of a bone and the preservation of its histology cannot be correlated. Despite the fact that bone, enamel and dentine are apatite, their structures are not identical. Thus, in a given site, the quality of their preservation is variable.

The main part of a mammal tooth is made of dentine, protected by the enamel, and by the bone when the tooth is still inserted in its alveolus. Nevertheless, dentine is rarely intact in fossil teeth. The pattern of parallel tubules in a mammalian tooth still inserted in the mandibular bone is blurred after some years in a soil (Figure 4a). In a single tooth extracted from a present-day regurgitation pellet, two aspects are visible (Figure 4b): some tubules are empty, and some tubules contain remains of odontoblast processes. Fractures in samples found in ancient regurgitation pellets show empty tubules (Figure 4c). Again, a correlation between the geological age of the sample and the quality of preservation does not exist. The tubules of teeth of large mammals are filled (Figure $4 \mathrm{~d}$ ) or empty (Figure $4 \mathrm{e}, \mathrm{f}$ ). The same diversity exists in dinosaur teeth (Figure $4 \mathrm{~g}, \mathrm{~h}$ ) and fishes (Figure $4 \mathrm{i}$ ).

The outer surface of most mammal teeth is enamel, so it is directly exposed to the diagenetic factors. The most surficial nonprismatic enamel layer can be removed after a stage of some years in a soil, so that the prismatic pattern is visible (Figure 5a,b). In a broken rodent tooth extracted from a present-day regurgitation pellet, the prismatic structure is also revealed (Figure 5c). In some fossils, the prismatic pattern is strongly etched, the dissolution depending on the orientation of the prisms (Figure $5 \mathrm{~d}$ ). The key hole pattern of the prismatic structure of a large mammal tooth is not very distinct (Figure 5e), but in another fossil site, the elongated crystallites of the prismatic structure are well-preserved (Figure 5f), although the tooth is broken and cannot be assigned to a taxon. Reptile teeth also show diverse preservation. The inner structure of the ill-defined prisms of some dinosaur teeth can be preserved (Figure 5g), as well as the growth layers (Figure $5 \mathrm{~h}$ ). Nevertheless, in other dinosaur samples, "prisms" have merged in larger structures, still perpendicular to the surface of the tooth (Figure 5i). The outer layer on the cap of durophage fish teeth is a complex arrangement of bundles of fibres that is well preserved in this Jurassic sample (Figure 5j). 

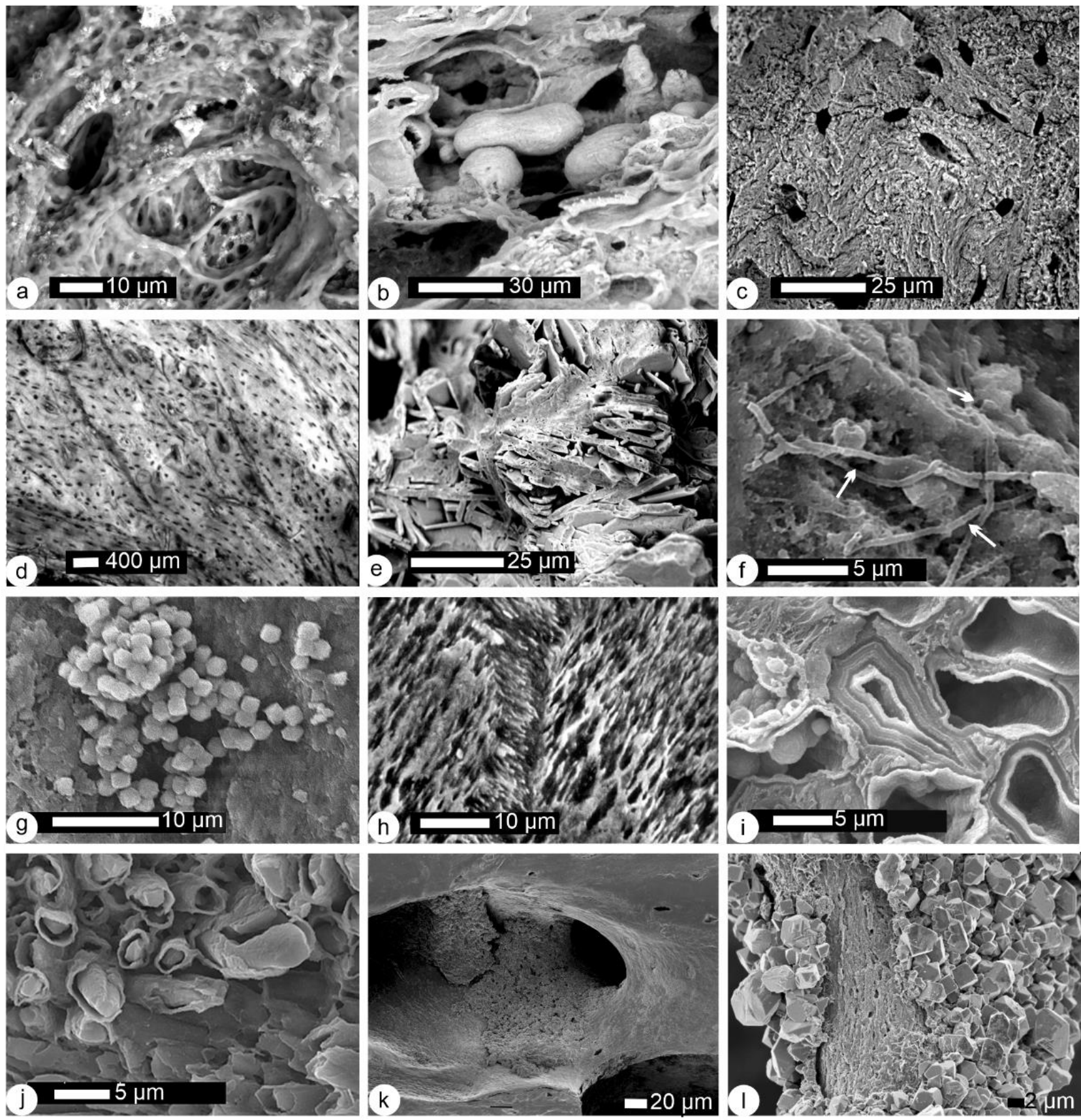

Figure 3. Microstructure of fossil bones-natural fractures. (a) Natural fracture in a well-preserved large mammal bone buried in a soil for an unknown time lapse. (b) Structures of unknown origin in a horse metapodial (France, 13th century). (c) In a rodent bone extracted from a modern regurgitation pellet, the inner structure is preserved. (d) Preserved periosteal compact bone with lamellae and scattered haversian bone (humeral shaft of Plesiomeryx cf. cadurcensis, France, Lower Oligocene); thin section. (e) Recrystallization and secondary deposits in a rodent bone (Morocco, Neolithic-Middle Palaeolithic). (f) Organic filaments (Fungi) on a large mammal bone (Malawi, Plio-pleistocene). (g) Secondary deposits on the outer surface of a fragment of a mammal bone (Thailand, Eocene). (h) Well-preserved structure of a fish bone (Malawi, Plio-pleistocene). (i,j) Structure of large mammal bones (probably Sirenia) is destroyed (faluns de Touraine, France, Miocene). (k) Secondary deposits in the alveolar region of a rodent bone (Olduvai, Pleistocene). (l) Same bone as in K under the secondary deposits, bone structure is visible. 

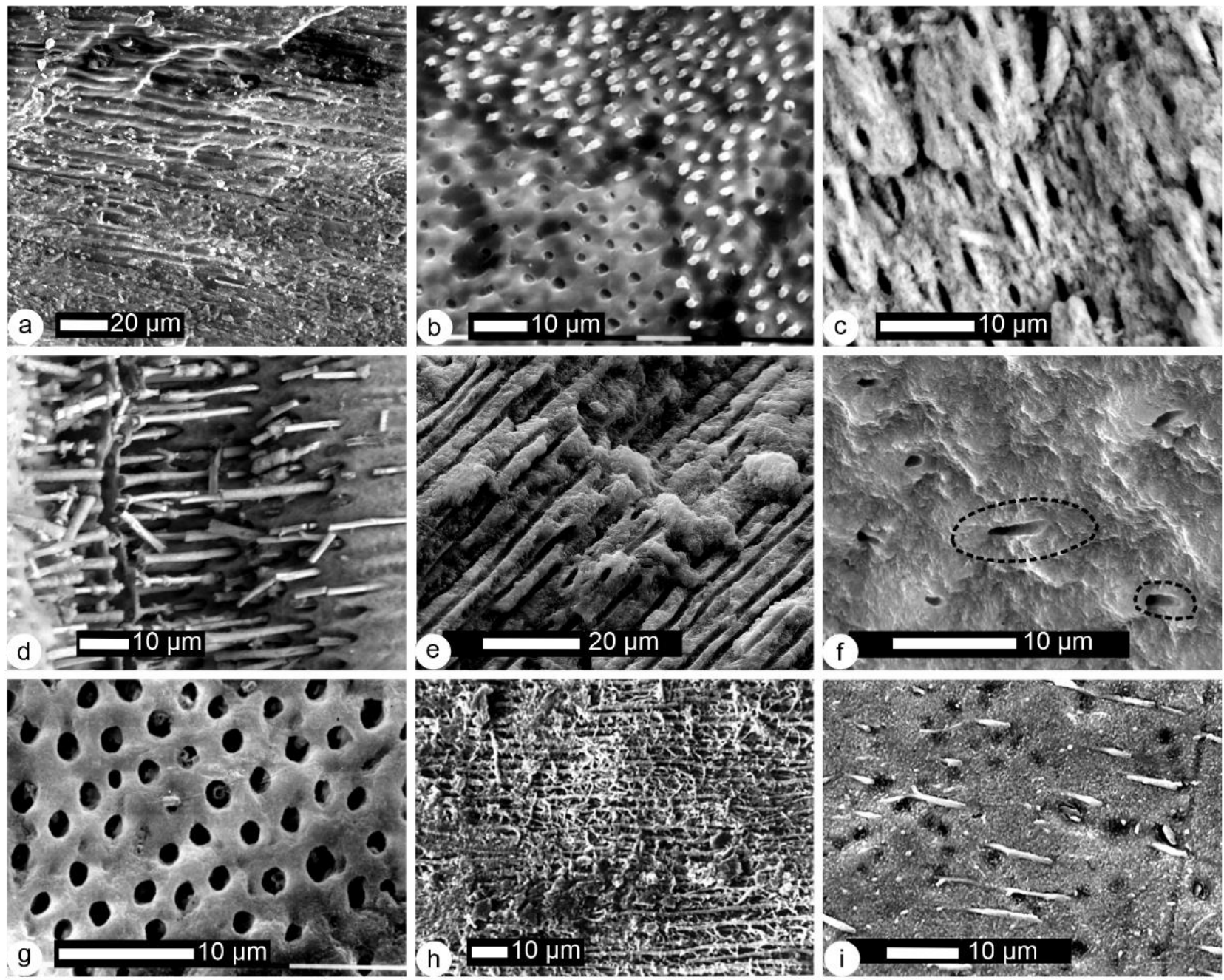

Figure 4. Microstructure of fossil dentine. (a) Parallel tubules are still visible in a large mammal tooth buried in a soil for an unknown duration. (b) Two preservation aspects (empty and filled tubules) in a single rodent tooth extracted from a modern regurgitation pellet (Algeria). (c) Oblique section showing the empty tubules in a rodent tooth (Olduvai, Pleistocene). (d) The dentinal tissue is dissolved, and the tubules are filled with secondary deposits (Moeritherium, Eocene, Algeria). (e) Empty tubules and secondary deposits in the orthodentine (Aureliachoerus, France, Miocene). (f) Oblique section showing empty tubules and the irregular peritubular dentine (dotted lines) (Kubanochoerus, Miocene, Lybia). (g) Tranverse section showing the empty tubules of the orthodentine of a dinosaur tooth (Tarbosaurus, Upper Cretaceous, Gobi Desert). (h) Parallel tubules filled with sediments and dentinal tissue partially dissolved in a theropod dinosaur tooth (Campanian, Canada). (i) Secondary filling of the tubules of a fish tooth (Malawi, Plio-pleistocene).

Present-day bone crystals are small, with typical sizes of $50 \mathrm{~nm} \times 25 \mathrm{~nm} \times 3 \mathrm{~nm}$. Their plate-like hexagonal morphology is difficult to observe using classical transmission microscopy [30], despite technical improvements. More or less hexagonal tablets are visible using atomic force microscopy (Figure 6a). Nevertheless, the most common aspect is the rod-like shape (Figure 6b). In this sample, crystallites are embedded in an organic matrix (Figure 6b), which is destroyed when the bone is buried for some years (Figure 6c). The smallest osteons are still visible in some fossil bones (Figure $6 \mathrm{~d}$ ), but neither the rod shape nor the platelet shape is preserved (Figure 6e). The prism decussation and the elongated crystallites are preserved in the enamel of a fossil rodent (Figure 6f,g), but not in a fossil large mammal (Figure 6h). Depending on the geological conditions, the organic matrix is more or less destroyed. In the fossil dentine displayed in Figure 6i, dark zones are probably 
organic remains. Variability of the preservation of organic components has been observed in different taxa [31,32]. It has also been shown that a tooth with a "well-preserved" prismatic structure is not so well-preserved at a nanoscale [33].
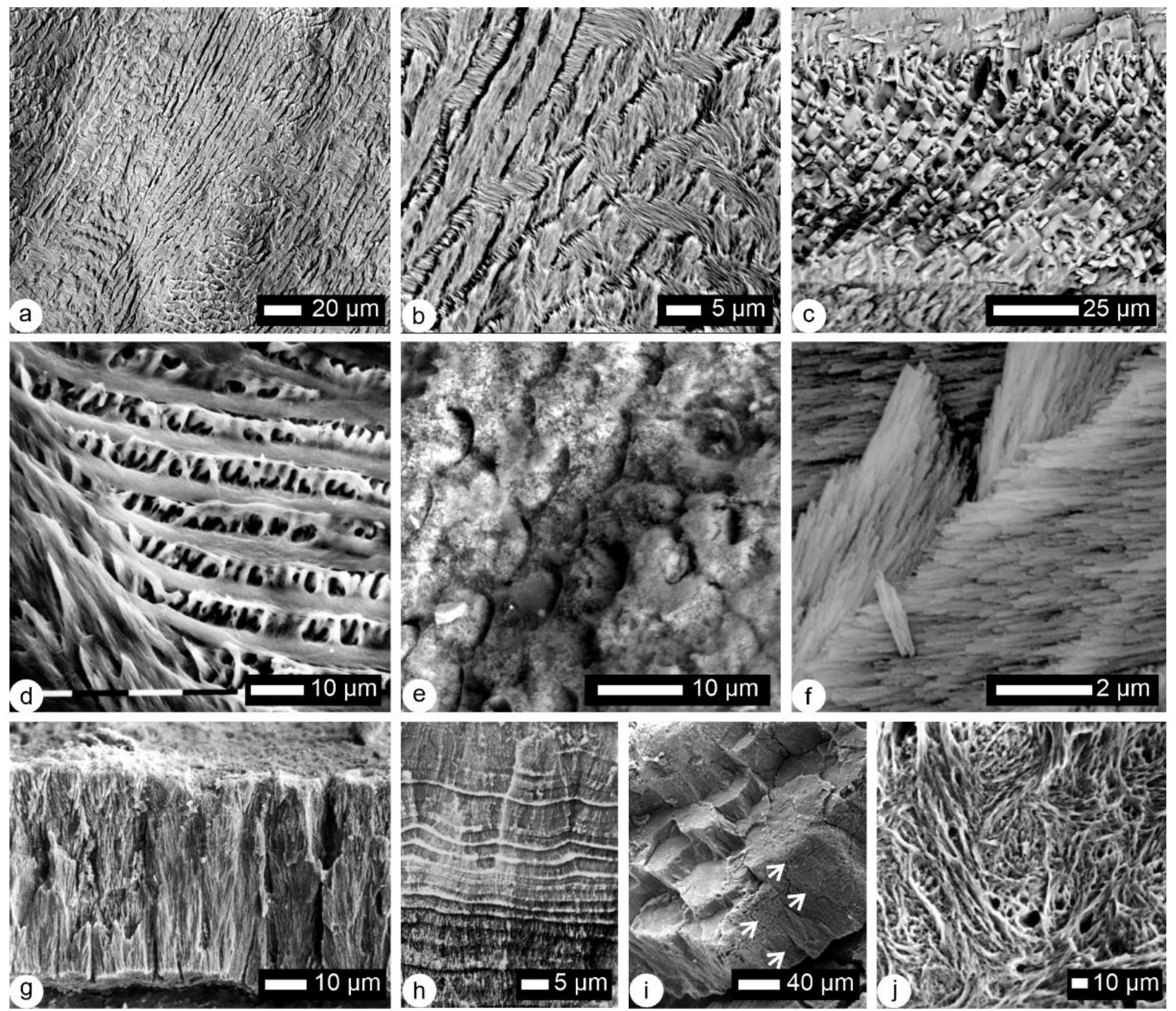

Figure 5. Microstructure of enamel. (a) The surficial non prismatic layer of the tooth has been removed and the complex arrangement of the prismatic enamel is now visible in this large mammal sample buried in soil. (b) Detail of the image in Figure 5a. (c) The prismatic pattern is revealed by the fracture in this rodent tooth extracted from a modern regurgitation pellet (Olduvai). (d) Dissolved enamel in a rodent tooth (Algeria, Pleistocene). (e) Residual pattern of the prismatic inner enamel layer in a large mammal tooth (Moeritherium, Eocene, Algeria). (f) Fracture of a rodent tooth showing the well-preserved acicular crystallites of the prismatic enamel (Malawi, Plio-pleistocene). (g) Vertical section in the pseudo-prismatic enamel of a dinosaur tooth (Carcharodontosarus, Albian, Tunisia). (h) Growth layers preserved in a tooth of a Rauisuchidae (Triassic, Germany). (i) Fragment of a dinosaur tooth showing secondary large prisms-unknown origin. (j) Well-preserved structure of the acrodine cap of Lepidotes (Jurassic, France). 

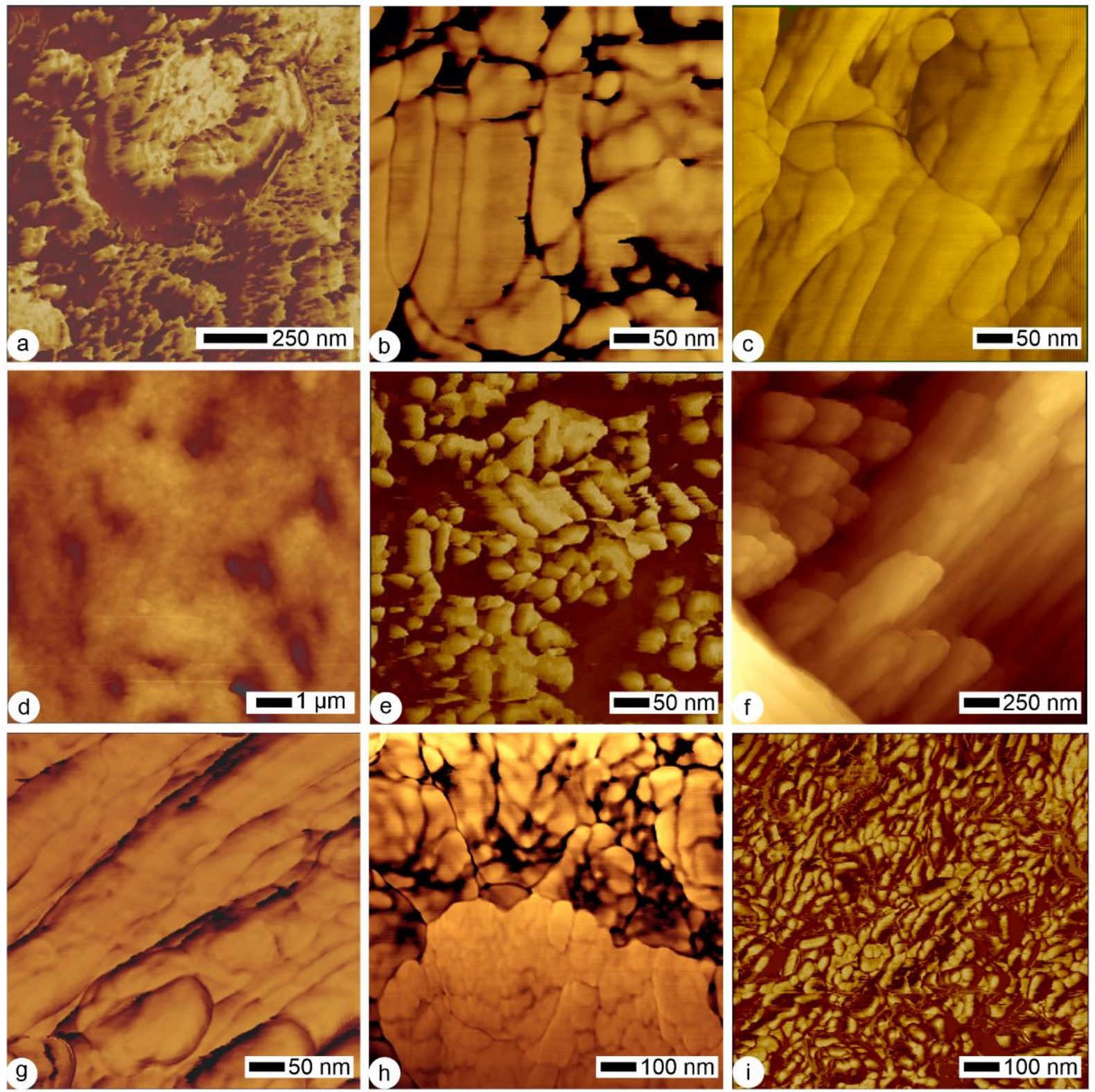

Figure 6. Nanostructures (atomic force microscope images). (a) Platelet crystal of a modern phalanx (Rattus); phase image. (b) Elongated crystals in a modern bone (Rattus). In phase images, the black zones are rich in organic components, while light orange-yellow zones are rich in mineral components. (c) In a small fragment of a bone buried in a soil, the black zones have disappeared, so the organic components have been destroyed, phase image. (d) Small osteons are still visible in a fossil rodent bone; height image (Plio-pleistocene, Morocco). (e) The plate-like habit of the crystallites is not preserved in this fossil rodent bone; phase image (Plio-pleistocene, Morocco). (f) The elongated crystallites of enamel are visible in a fossil rodent incisor; height image (Plio-pleistocene, Morocco). (g) Detail of the parallel elongated crystallites of an enamel prism of the sample shown in Figure 6f; phase image. (h) Altered enamel in a fossil large mammal; phase image (Malawi, Plio-pleistocene). (i) Dentine in a large mammal fossil (Kubanochoerus, Miocene, Lybia).

\subsubsection{Bulk Composition}

Like all biogenic minerals, bones and teeth are a mixture of organic and mineral components. It is well-known that the ratios of organic and mineral contents differ in enamel, dentine and bone, but most often values are given without any precision. However, mineral and organic components do not have the same density, so the organic/mineral 
ratios are clearly different when calculated from weight or volume [34]. For example, the mineral represents $49 \%$ of the volume of bone and $70 \%$ in weight [34]. Thermogravimetric analysis (TGA) is a rapid and accurate technique using a few milligrams of sample: it measures weight changes in a material as a function of temperature (or time) under a controlled atmosphere. Organic components are more sensitive to diagenetic alterations: they are a food resource for bacteria and fungi, so in most fossils, the organic-mineral ratio is lower than that of present-day samples. In thermograms, the low organic content of the fossils is apparent in large and small mammal bones (Figure 7) [35,36]. The ratio can be also estimated from infrared analyses, but TGA is the only direct technique.

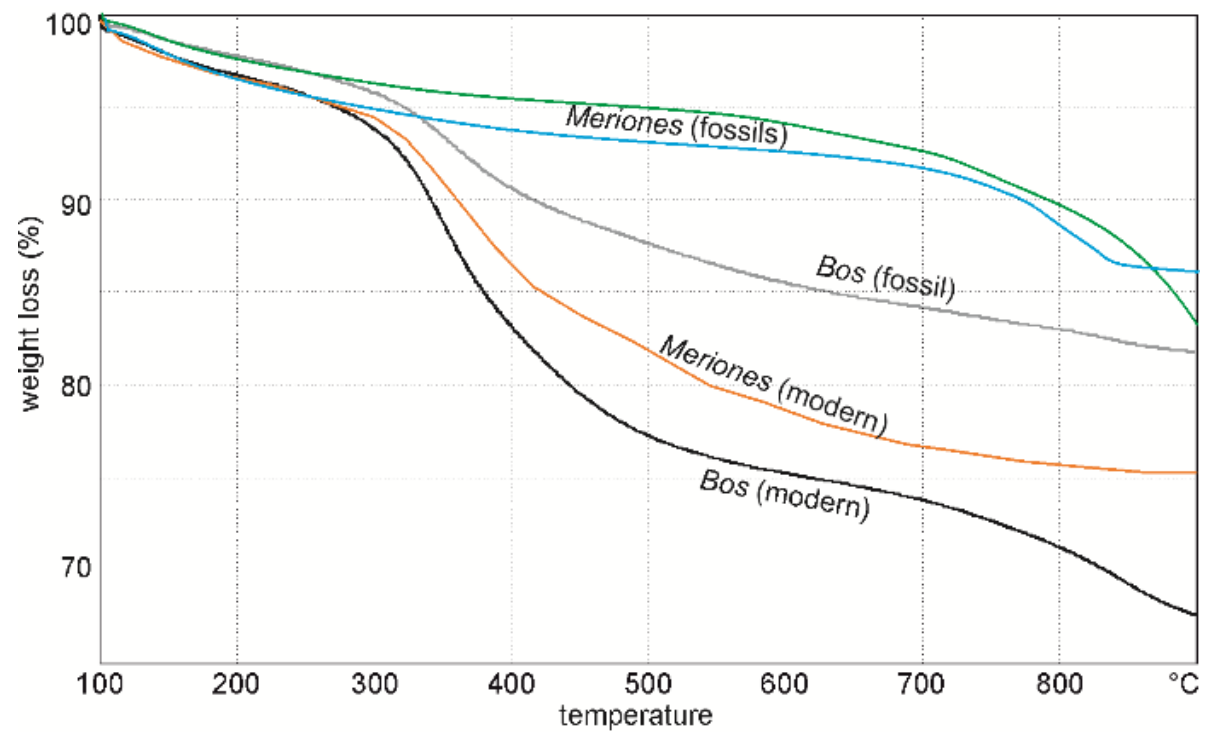

Figure 7. Thermogravimetric profiles of modern and fossil bones showing that the organic content is low in fossil samples.

\subsubsection{Mineralogical and Crystallographic Modifications}

Bones and teeth are biocomposites: the mineral is apatite, but its precise nature is still controversial (carbonate hydroxyapatite? hydroxy(l)apatite? carbonated apatite? dahllite?) [37-42]. This apparent diversity is due to the presence of many trace elements (sodium, potassium, zinc, magnesium, etc.), together with the lack of stoichiometry of bone apatite. X-ray diffractograms show that the main peaks are present in a recent bone (Figure $8 \mathrm{a}$ ), but they are not sharp as they are in a non-biogenic apatite. Thus, the crystallinity of the bone apatite is lower than that of the true crystal. It must be noticed that from the spectra, the unanswered question is whether the low crystallinity is due to the presence of amorphous apatite or not. Most fossil bones are preserved in apatite, but the peaks are sharper, indicative of a higher crystallinity. Secondary minerals are also detected (Figure 8a). From X-ray analyses, the morphology of the crystals can be estimated, but depending on the used parameters, results differ in a single sample [43-45].

Infrared and Raman spectrometries are also used to study bioapatites: information about the molecular components and structures are presented as a spectrum of absorption bands for both organic and mineral components, amorphous or crystals. Moreover, not only spectra but also maps can be acquired. The difference between the apatite of bone, dentine and enamel has been evidenced [40,46]. To date, most studies are dedicated to recent bone and enamel of humans and bovids because of their medical interest. The abundant organic matrix is clearly shown by the amide bands in a recent dry bone and in a recent rodent bone extracted from a regurgitation pellet of a bird of prey (Figure $8 \mathrm{~b}$ ). From the ratio of the $v 4 \mathrm{PO} 4$ doublet, the mineral is hydroxyapatite [47]. 

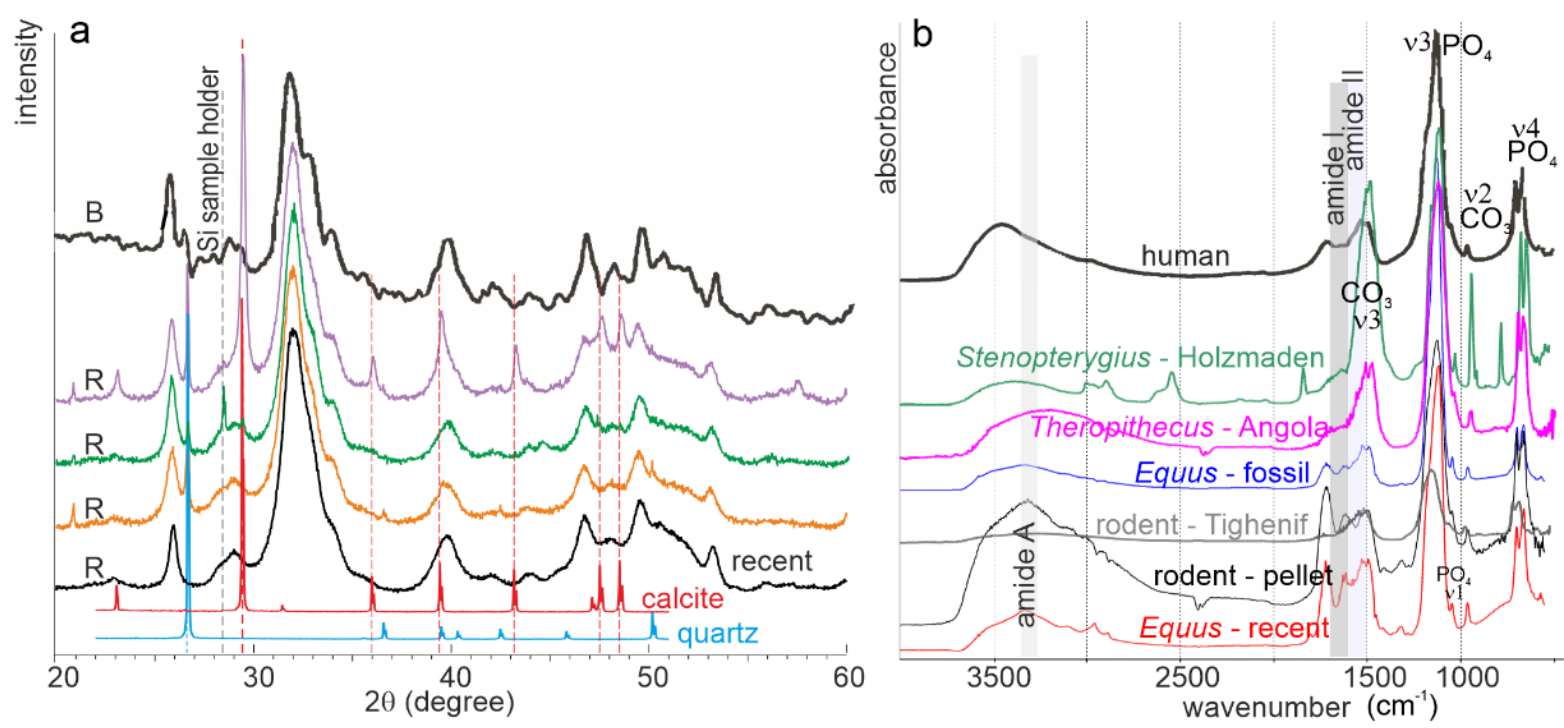

Figure 8. (a) X-ray diffraction patterns of some fossil rodent (R) (Morocco, Plio-pleistocene) and a bovine bone (B). The diffraction patterns of calcite and quartz are indicated. Bovine fossil bone redrawn from [48]. (b) FTIR spectra of a modern metapodial (Equus), a rodent bone extracted from a regurgitation pellet, diverse fossil samples and a human bone (VI-WIII c., Italy). Human bone redrawn from [48]. Organic bands (amides A, I and II), carbonate and phosphate are indicated. $\checkmark 4 \mathrm{PO} 4$ band is used to estimate the crystallinity and depends on the minor element content.

Several ratios are used to infer the crystallinity from infrared spectra. They can be calculated from height or area ratios $[43,49,50]$. Modifications of the mineral are also detected using infrared spectrometry. The $\mathrm{CO}_{3} / \mathrm{PO}_{4}$ index [51], substitution between $\mathrm{CO}_{3}$ and $\mathrm{PO}_{4}$ and $\mathrm{OH}[52,53]$, amount of type $\mathrm{B}$ carbonate to phosphate [54], amount of type $\mathrm{A}$ carbonate to phosphate and the relative amount of $\mathrm{B}$ to $\mathrm{A}$ site carbonate [55] are indicative of compositional changes. A decrease in organic components, a higher $\mathrm{CO}_{3}$ content and a higher crystallinity have been described in vertebra of fossil sharks [41].

Thus, infrared data offer a large range of potential criteria to unravel the diagenetic history of fossil bones and teeth, thanks to their ability to be sensitive to mineral and organic components. Besides all the data obtained from localized spectra, Raman and infrared spectrometries can be used to map the samples. Again, most available data have been acquired on recent tissues [56-60]. Nevertheless, differential chemical modifications have been revealed on dentine and enamel. Recent rodent incisors extracted from regurgitation pellets from various birds of prey show chemical different alterations so that it will be possible to identify the predator [61]. From raw data, maps can be extracted to assess the quality of the preservation; such maps have been used in fossil rodent incisors [61], in human bone remains [62] and in dinosaur bones [63]. Moreover, map ratios have emphasized the differences between the samples, as shown in recent bone [64]. The compositional difference between dentine, enamel and the enamel-dentine junction is visible in the map of a recent rodent incisor at $961 \mathrm{~cm}^{-1}\left(\vee 1 \mathrm{PO}_{4}\right)$ and $1238 \mathrm{~cm}^{-1}$ (amide III) bands (Figure $9 a, b$ ). The alteration due to the digestive process by a bird of prey is visible in a tooth extracted from a recent pellet of regurgitation (Figure 9c). Various alterations are displayed in the maps of the $v 1 \mathrm{PO}_{4}$ band in rodent incisors in some levels of an archaeological site [61,62]. All teeth come from the same species of Meriones (Figure 9d-g). To estimate the distributions of the modifications between the organic and mineral content, data between 900 and $1200 \mathrm{~cm}^{-1}$ and between 1580 and $1720 \mathrm{~cm}^{-1}$ have been integrated for the mineral and organic content, respectively. Then, these maps are ratioed. The changes induced by the digestion by a bird of prey and in a fossil tooth are emphasized in such maps (Figure 9h,i). 

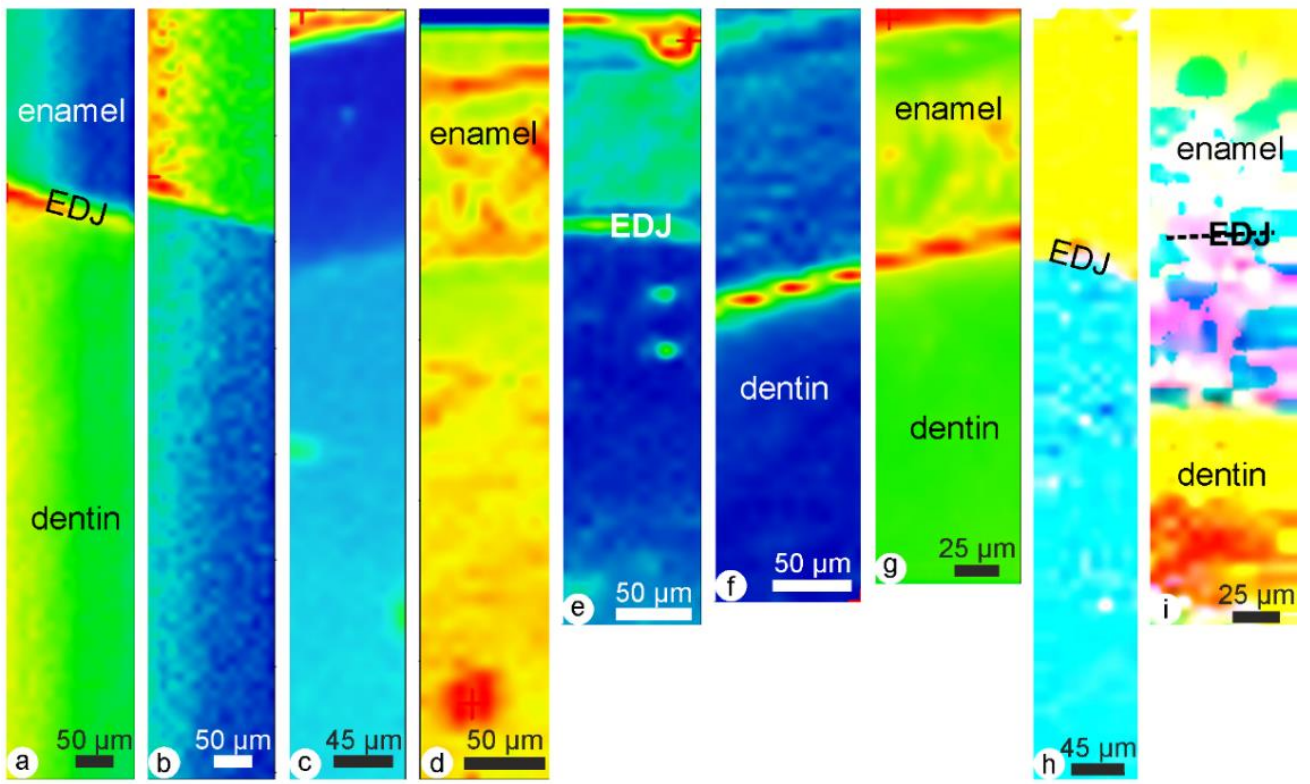

Figure 9. Infrared maps of Meriones incisors. (a,b) Modern tooth. (c) Tooth extracted from a modern regurgitation pellet. (d) Tooth from level I; (e) Tooth from level 3. (f) Tooth from level 7. (g) Tooth from level 8. (h) Ratio of maps between 900 and $1200 \mathrm{~cm}^{-1}$ for the mineral content $\left(\mathrm{PO}_{4}\right)$ and 1580 and $1720 \mathrm{~cm}^{-1}$ for organic content, for a tooth extracted from a regurgitation pellet (Bubo). (i) Ratio of maps between 900 and $1200 \mathrm{~cm}^{-1}$ for the mineral content $\left(\mathrm{PO}_{4}\right)$ and 1580 and $1720 \mathrm{~cm}^{-1}$ for organic content, for a tooth from level 3. All levels from El Harhoura 2 cave (Morocco, late Pleistocenemiddle Holocene). A $961 \mathrm{~cm}^{-1}$ band ( $v 4$ used to visualize $\mathrm{PO}_{4}$ Distribution; $1238 \mathrm{~cm}^{-1}$ band used to visualize amide III distribution). Abbreviation EDJ: enamel-dentine junction.

\subsubsection{Chemical Modifications (Mineral and Organic Components)}

Bone, enamel and dentine are apatite, but their chemical contents are not identical. Geological and palaeoenvironmental applications of the apatite-group minerals are directly linked to their chemical compositions. It is therefore important to detect the substitutions that control the compositional variation in apatite, because these substitutions occur even in bone or tooth still in apatite.

Thanks to electron microprobes, the elemental chemical contents can be known with high precision. Using polished surfaces, it is not necessary to separate enamel and dentine, a very difficult task in small mammals, especially for molars with complex shapes. Moreover, it is possible to observe the samples to check the quality of the preservation of the microstructure of the dentine zone. The differences in present-day enamel, dentine and bone concern the major (P and Ca) and minor elements (Figure 10a,b). Depending on the post mortem history of the fossils, bone, dentine and enamel are depleted or enriched in elements (Figure 10a-d). The composition of the embedding sediment plays a role, but the structure of the tissue is also important: bone and dentine are rich in organic matrix, and they are porous (tubules, blood vessels). This porosity favours both dissolution and secondary deposits. Quantitative data are used for statistical comparisons, but qualitative data can be used to estimate the chemical homogeneity of a sample and to detect secondary minerals [65]. In present-day teeth, the Ca content of enamel is higher than that of dentine, as displayed by the darker brown colour in maps (Figure 10e). In a fossil tooth of the same species, the intensity of colour is similar in enamel and dentine (Figure 10h). Nevertheless, using only maps, we do not know whether the dentine is enriched in $\mathrm{Ca}$ or whether the enamel is depleted in Ca. In a present-day rodent incisor, $\mathrm{Mg}$ content is very high (Figure 10c), and it is displayed by the darker brown colour (Figure 10f), but the colours are similar in a fossil sample (Figure 10i). The differences in Na contents in a present-day tooth are not visible in the fossil sample (Figure 10g,j). It must be noticed that the two 
sub-layers of the enamel are visible, as is their inner structure. So, quantitative analyses and qualitative maps are not redundant.
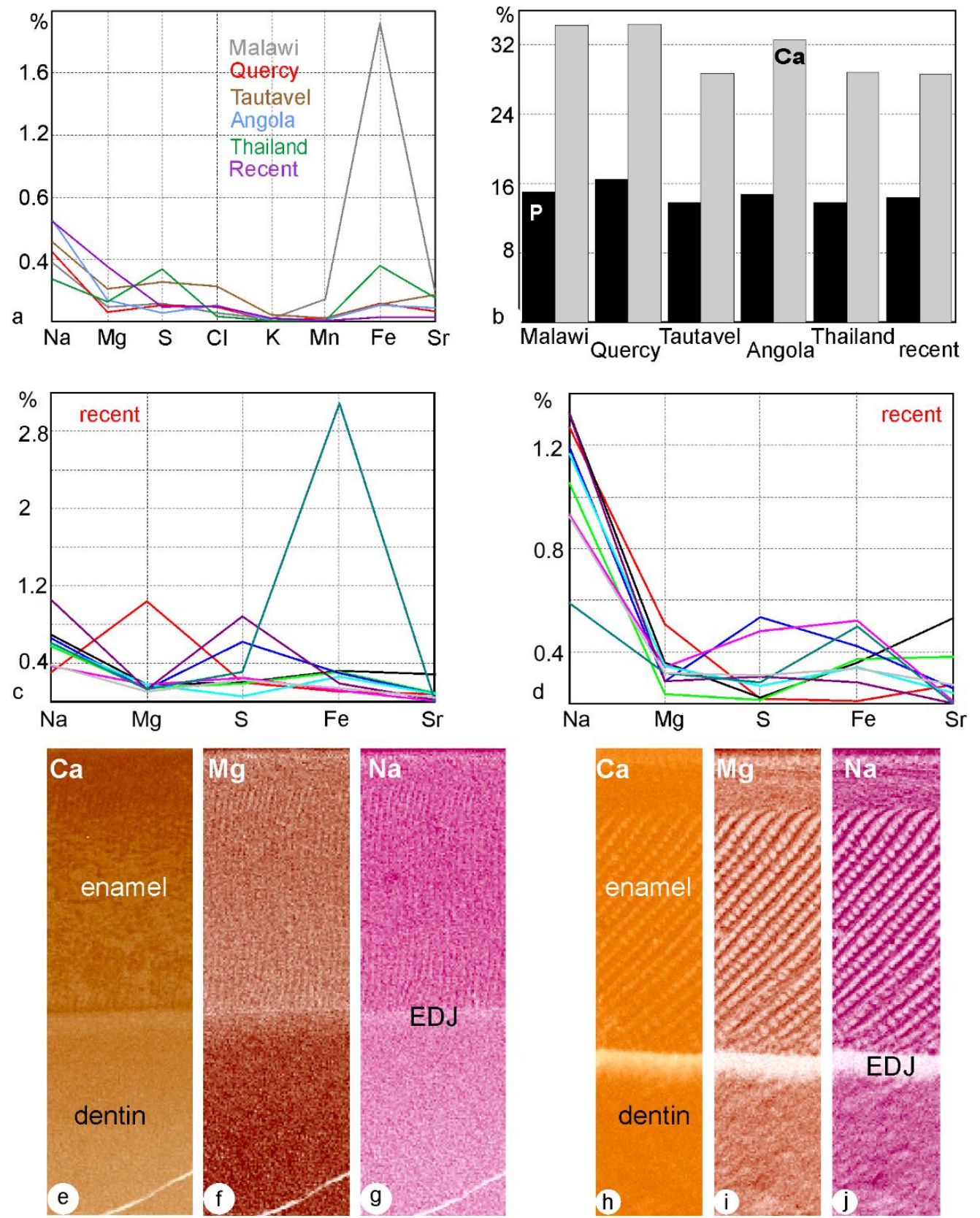

Figure 10. Average elemental composition of modern and fossil bones and teeth (\% in weight). (a) Minor element contents of bone of large mammals. (b) Major element contents of the same bones displayed in 10a. (c) Minor element contents of the dentine of reptilian teeth. (d) Minor element contents of the enamel of the same reptilian teeth. (e-g) Distribution maps in a modern rodent incisor. (h-j) Distribution maps in a fossil rodent incisor from El Harhoura 2 cave (Morocco, late Pleistocene-middle Holocene). Abbreviation EDJ: enamel-dentine junction.

Infrared spectrum provides data on both organic and mineral components. In a fossil rodent bone, the $v 4 \mathrm{PO}_{4}$ doublet is modified, probably related to a small increase in $\mathrm{Cl}$ content as shown by electron microprobe analyses, and the content in organic matrices is low [66]. $v 3$ and $v 4 \mathrm{PO}_{4}$ doublets of bones from Holzmaden, Germany are similar to those described for fluor-enriched samples (Figure 8b). High $\mathrm{Sr}$ and Ba contents also shift some bands [47,67]. Brophy and Nash [68] and Sakae et al. [69] illustrated spectra of apatitic 
fossil samples with chemical alterations. Fluoridated apatite shows two bands close to 718 and $692 \mathrm{~cm}^{-1}$ [70]. Fluor content can be known from FTIR spectra using the ratio between the $605 \mathrm{~cm}^{-1}$ and $567 \mathrm{~cm}^{-1}$ bands and a strong band at $1096 \mathrm{~cm}^{-1}$ [43].

The ratio of two amide bands (amide I and amide A) to phosphate and carbonate ions estimates the changes in organic and mineral contents $[42,71]$. The alteration of the organic matrix can be quantified using two ratios: amide I/amide A, and amide I/amide II [42,71,72]. Raman spectroscopy has received little attention, but diagenetic changes have been detected in fossil bones and teeth [73-75].

Collagen is the most studied organic component in vertebrate skeletons. It is the most abundant component of bone and dentine and has been detected in enamel [76]. It is often assumed that the insoluble organic matrix extracted from bone is collagen, but a closer examination shows that other molecules are also present (Figure 11). To analyse the organic matrices, the mineral part is removed using acidic hydrolysis or ion exchange resins. Infrared spectra show that in present-day bone, the apatite has been removed (Figure 11a), but not in fossil bones, despite diverse preparative procedures (Figure 11b). Unfortunately, the main band for $\mathrm{PO}_{4}$ and that of the sugars coincide. Collagen is a family of protein $[77,78]$, and its average amino-acid is considered to be characteristic with high content in glycine, proline and hydroxyproline [79], so it is often said that collagen is preserved without checking its structure or imaging it. Amino acid analyses show that in a present-day bone, soluble and insoluble matrices differ (Figure 12a). Both soluble and insoluble matrices compositions are modified (Figure 12a). Monosaccharides (or simple sugars) differ in the soluble matrices extracted from two present-day bones. The preservation in their fossil counterparts is also variable (Figure 12b).

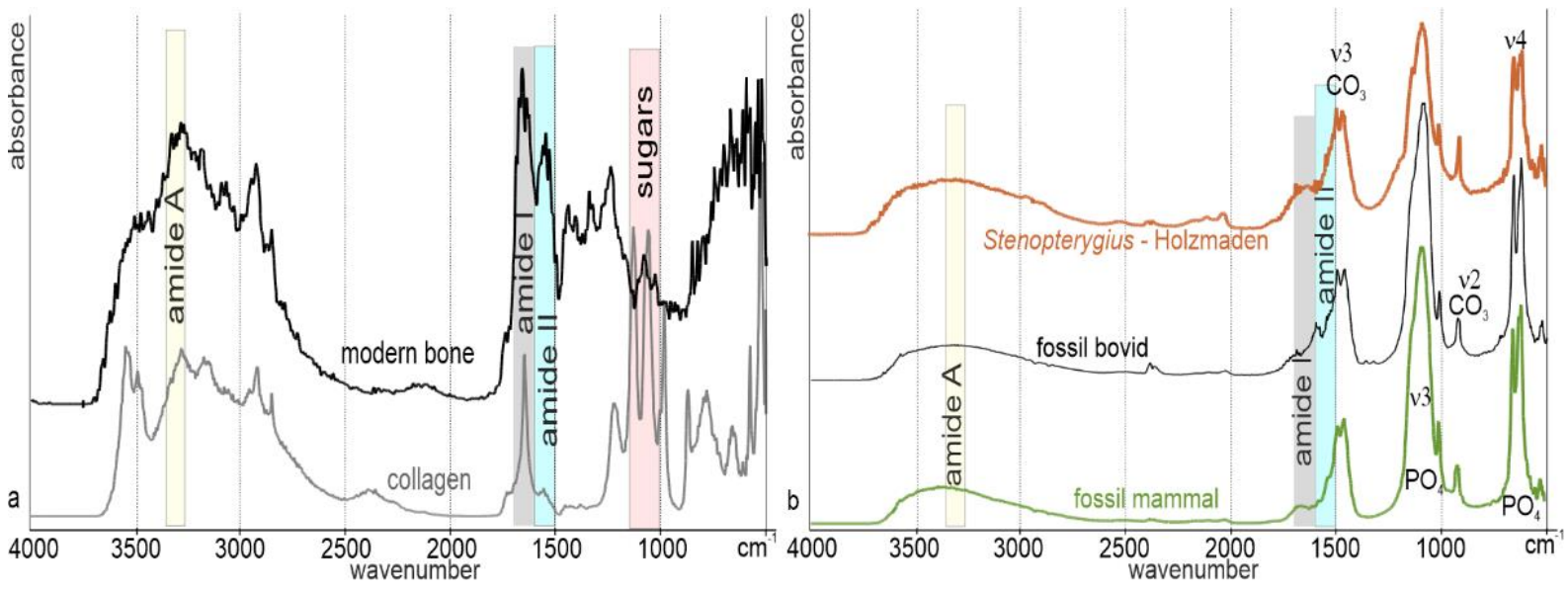

Figure 11. FTIR spectra of insoluble organic matrix from collagen and extracted from a modern bone (Bos) (a) and extracted from fossil bones (b). The insoluble matrix of the modern bone is not pure collagen. Insoluble matrices of fossil bones are not fully demineralized, as shown by $\mathrm{CO}_{3}$ and $\mathrm{PO}_{4}$ bands. Stenopterygius: see also Figure $8 \mathrm{~b}$.

Molecular weights of the soluble organic matrices extracted from fossil bones are often smaller than those of their present-day counterparts [19], and using a refractometric detector, it is also visible that sugars are strongly destroyed by diagenesis (Figure 13a). Few data are available on sugars and lipids in bone, and they are quasi-absent for teeth. Using Sudan B black staining, Pawlicki [80] has been able to reveal the presence and distribution of lipids in dinosaur bones. Mucopolysaccharides were also revealed in dinosaur bones using diverse staining procedures [81]. Osteocalcin has been preserved in bovid bones (13 million years old) and rodent teeth (30 million years old) [82] and in some dinosaur bones [83]. Such data can provide clue for evolution. The distribution of lipids and sugars are sometimes similar to that of present-day bones. Acyl lipids are in low concentration in ancient mammals bones of diverse origins and geological age, while the diagenetic 
degradation of cholesterol is variable [84,85] (Figure 13b). Some lipids are the results of bacterial activity.

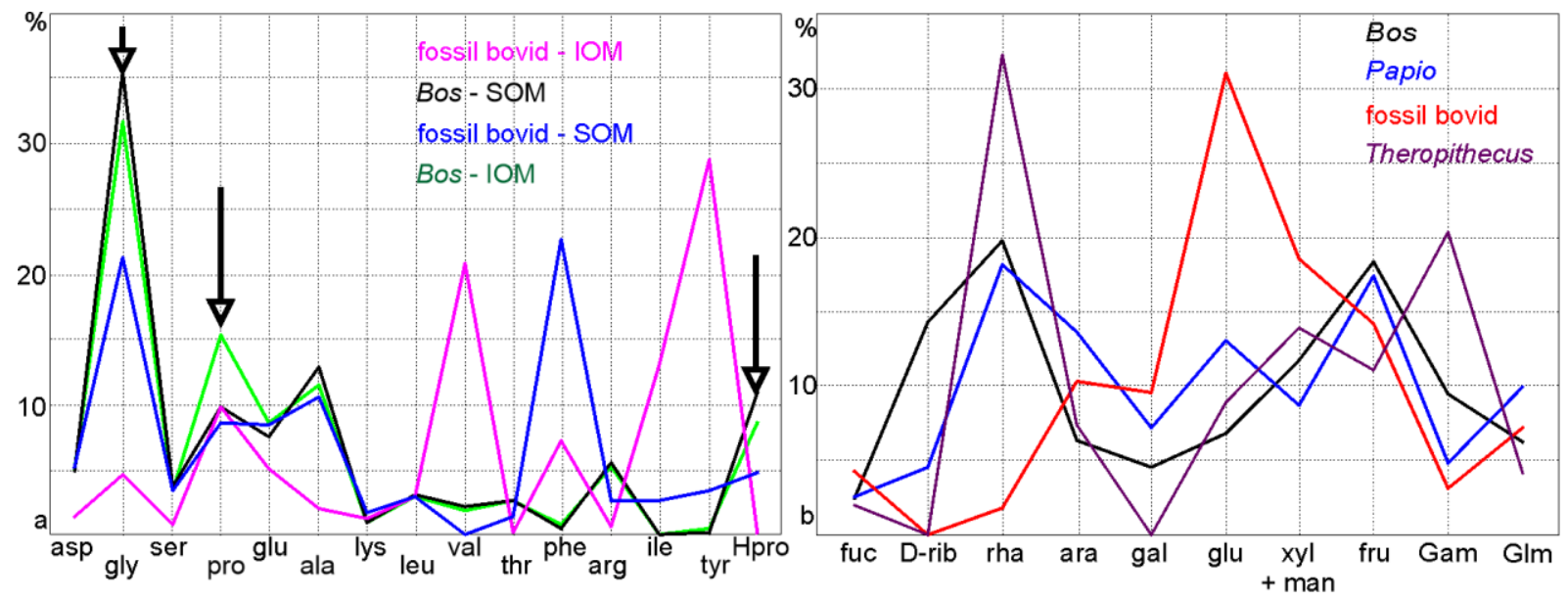

Figure 12. (a) Amino acid composition of a modern and a fossil bovid bone. (Arrows) Amino acids said to be characteristic of collagen [79]. (b) Monosaccharide composition of the soluble organic matrices extracted from two modern bones and their fossil counterparts. IOM: insoluble organic matrix, SOM: soluble organic matrix.
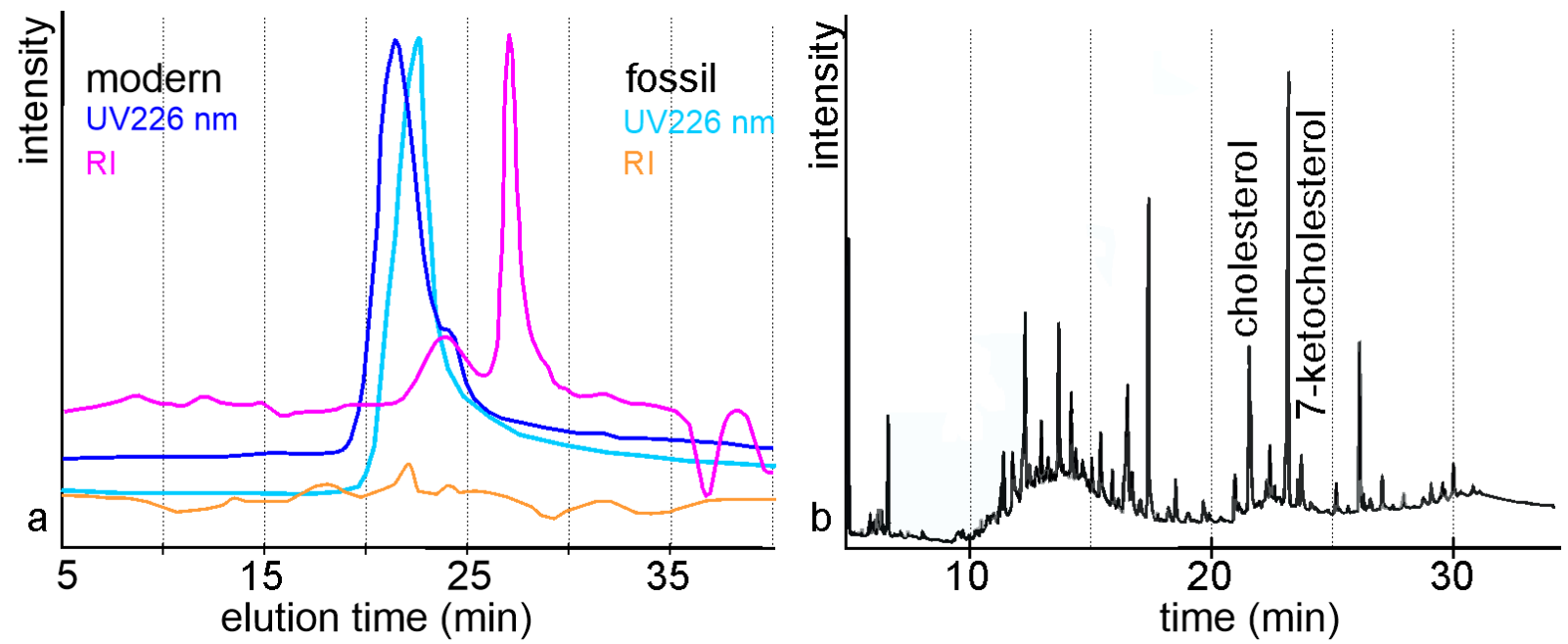

Figure 13. Organic matrices. (a) High-performance liquid chromatography of a modern and a fossil mammal bone (Thailand, Eocene); the large molecular weights of the modern bone are replaced with smaller molecules in the fossil. (b) Partial gas chromatogram showing the preservation of some lipids in a whale bone collected in the permafrost (70,000 years old). Redrawn from [84].

Collagen is the most studied protein of ancient bones, and its presence is often used as a good sign to find DNA $[85,86]$. DNA is located in cells, so it can be found in bones and in the cellular extensions in the tubules of dentine. Enamel does not contain DNA. At first, it was hoped that DNA analyses would be able to resolve all the questions dealing with phylogenetic and evolution [87]. Unfortunately, the behaviour of DNA is similar to that of other organic molecules: large molecules are hydrolysed and are reduced in small fragments [88,89] despite successful analyses [90,91].

\section{Predation, Digestion or Diagenesis?}

One of the aims of palaeontology is to understand past biodiversity. Biodiversity typically measures variation at the genetic, the species and the ecosystem levels. Thus, to be able to identify the species of a fossil is enough for this purpose, and morphology 
and size are the main criteria. In some cases, the microstructure (enamel, dentine) is also used, because they are typical of taxa [92-94]. When the aim of the study is to reconstruct the palaeoenvironment and the geological history of a region, it is important to detect the biases induced by the mechanisms of fossilization. Identifying the prey is useful to reconstruct the palaeobiodiversity, but identifying the predator improves our knowledge of the past biocoenosis. Then, analyses of the structure and composition are of great interest to understand the alterations. Depending on the taxa, bones are more or less resistant to fracturation, dissolution and other weathering and decay agents, so the ratios of taxa of the thanathocoenosis used to infer the past dryness or temperature of a region are not those of the biocoenosis. Geochemical and isotopic ratios are also modified.

To identify the agents responsible for assemblage accumulation and deposition is the most difficult task facing the palaeontologist $[95,96]$. The processes involved in formation of assemblages are still not well understood, although the quality of the reconstruction of the past/fossil environments depends on this knowledge. Classical taphonomic studies consider only one or two criteria: bones and teeth frequencies, fragmentation, are used to try to identify the predator for small and large mammals [97]. Although these quantitative criteria appear to be relatively simple, numerous variations exist, e.g., minimum number of elements, minimum number of individuals, so comparisons are difficult [98]. Then, surface modifications of bones and teeth were observed. Identification of the origin of tooth marks is difficult, and the results of digestion and geological modifications are more or less similar [99,100]. Most studies are based on small mammals in pellets regurgitated by birds of preys [101,102] and on lions and hyenas for large mammals [103]. The remains due to small mammalian carnivores are sometimes described $[9,10,104]$. It must be noticed that such studies are usually devoted to "ancient" sites (Plio-pleistocene included). Nevertheless, controversies are not rare. These techniques are the first to be used because they are non-invasive and the samples can be recovered after the observations, and no expensive material is needed. Although we may not know how much the digestion modifies the tissue, we know that it does. Thus, the behaviour of a digested skeletal element and that of a nondigested one are not identical in the burial and fossilization processes.

To resolve the controversies, new criteria can be added, based on the microstructure and the composition of the samples. The diversity of the preservation has been evidenced in fossil bones from their amino acid and isotopic compositions [105]. Several factors play a role, and their complex interplay is not yet unravelled, despite some attempts [106,107]. The roles of various factors are sometimes emphasized [108]. Bones and teeth are often dissolved, and then holes are filled with secondary crystals or sediments. Such modifications are easily detected using thin sections or SEM images. Localized chemical analyses show that the compositional changes are heterogeneous, or they evidence gradients from the outer surface to the inner cavity of the bone or tooth [109]. Fossils can be enriched in chemical elements related to the geological environment [110,111] (Figure 14) or depleted [66] (Figure 10). Many studies attempt to use the distribution of trace elements in fossil bones to determine palaeonutritional information of past organisms. Among them, $\mathrm{Sr}, \mathrm{Ba}, \mathrm{Zn}$, and $\mathrm{Mn}$ have been accepted as reliable. In Olduvai samples, the high $\mathrm{Sr}$ and Ba contents show the "contamination" of the bones [32,110,111].

Exchanges between bones or teeth and sediment or soil are more difficult to detect and to estimate. The interrelations between apatite, fungi and soil are complex [112,113]. Sometimes, filaments or small granules are assigned to fungi or bacteria [108], but the molecular exchanges need the extraction of the organic components to be revealed. A model trying to explain the diagenesis of proteins has been proposed by Bada et al. [114], but lipids and sugars also exist. As for chemical elements, organic molecules are incorporated into the tissue during the fossilization process or are expelled from the tissue to the external sediment [115-117]. 


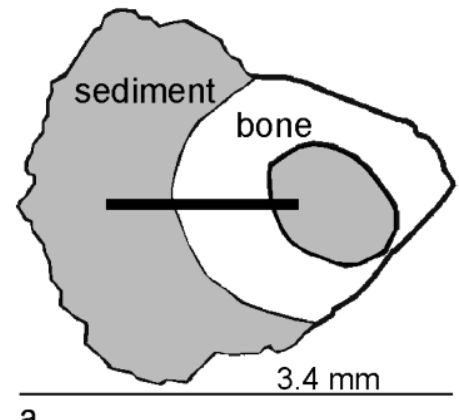

a

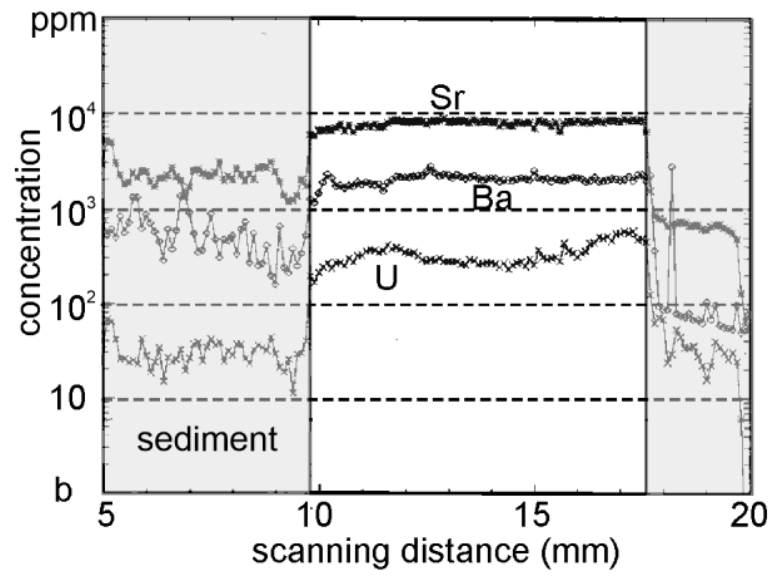

Figure 14. (a) Section showing the locations of the analysed profiles. (b) Ba, Sr and U profiles through the fossil bone from Olduvai, Ngorongoro (Tanzania) shown in Figure 4a. Redrawn from [109].

Palaeontologists are not pleased when the samples must be "prepared" (e.g., crushed, cut, demineralized), so these kinds of analyses are more abundant for small mammals and bones. Teeth are more useful to identify taxa, and dentine and enamel are difficult to separate for detailed analyses of the mineral and organic components. Not all of the conflicts and problems have been solved, and new questions are raised. For example, modifications of the chemical elemental composition of bone, enamel and dentine are not identical in a single fossil site, because the structure and initial compositions of these tissues differ [118]. Very few data are available on the structure and composition of present-day bones or teeth rejected in regurgitation pellets or faeces. To crush and to demineralised bone, enamel and dentine is the only way to obtain "details" on the organic matrix they contain.

Bone is rich in organic matrix [34], so it is often supposed that it is the best choice to collect a high amount. The results are often disappointing, and at the end of the procedure, the bottle containing the dried matrix seems to be empty. Ultraviolet fluorescence allows some data to be obtained [61]. A fresh bone is rich in cells, but this abundance attracts insects, worms, bacteria and fungi looking for food, so that only low amounts of organics are preserved. This is why some decades ago, it was generally believed that compounds such as proteins could not be preserved in sedimentary deposits. Progress in analytical systems, with high sensitivity and resolution, now allows us to study these organic components.

Whatever the studied criteria, the problem is complex because the diagenetic behaviour of an organism depends on intrinsic features (size, shape, structure, composition) and from extrinsic factors (temperature, sediment composition, predation, etc.). In natural environments, all these factors are mixed and active. To understand the role of a given factor, actualistic experiments are done. Measurements of the inner parameters during the digestion are difficult, so that they are measured in freshly rejected pellets. These experiments show the importance of the age of the bird of prey, the number of meals, etc. $[28,119]$. Another way is to simulate in vitro the process of digestion [22,120]. Similarly, transformations occurring during the burial and past burial events can be studied in vivo and in vitro [121]. Both are rare and for short term data. In vitro experiments have been done on mammal teeth [122], whereas in vivo experiments have been done on mammal teeth [123]. Weathering experiments are mainly done in mammal samples, but some data about squamates are available. The comparison of modern "weathered" and fossil bones shows that weathering marks are dominant in fossil bones, whereas digestion changes are more important in modern bones [124].

\section{Some Pitfalls}

\subsection{The Perfect Preservation}

A fossil is often said to be perfectly preserved when its shape is preserved. From this assertion, the geological history is reconstructed, and isotopic analyses are done to 
know palaeotemperatures, chronology is established using electron spin resonance (ESR), ${ }^{14} \mathrm{C}$ or racemization of amino acids, diets are inferred from the ${ }^{12} \mathrm{C} /{ }^{13} \mathrm{C}$ isotope ratio, etc. Unfortunately, many studies do not examine the structure of the sample, and basic mineralogical analyses or thermogravimetry analyses are not done.

For example, ESR-U/Th were done on dental enamel, whereas OSL was done on enamel, dentine and cement collected at El Harhoura 2 cave (Morocco, NeolithicMiddle Palaeolithic). There is a discrepancy between ages obtained by ESR (electron resonance spin)-U/Th and OSL techniques, but the examination of the microstructures and compositions of the fossils show they are diagenetically modified [118], although their shape is preserved.

\subsection{Technical Pitfalls}

Bones and teeth, present-day or fossil, are hybrid composites (organo-minerals). So, their study encompasses a large range of geological and biological techniques. Thin sections are usually observed in natural light, but more data are obtained using a polarizing petrographic microscope and UV fluorescence. They can be stained with more or less specific dyes. Unstained sections can be used in Raman and infrared microscopy, electron and ion microprobes, so that it is possible to assess the quality of the preservation of the tissues and to differentiate the composition of the tissue and that of the secondary fillings.

Quantification is often considered to solve all problems in this context. For example, it is possible to quantify the crystallinity of a tissue from infrared spectra. The splitting factor or crystallinity index can be calculated from band height (sf-h) or area (sf-s) ratios (Figure 15). For rodent bones extracted from the successive layers of a cave, both calculations show that modifications have occurred, but they are not fully concordant. It must be noticed that the explanation of the changes is not so clear. Amorphous and crystalline Ca phosphates are known in bone. Is an increase in the crystallinity index due to the crystallization of the amorphous Ca phosphate during the diagenesis, or is the amorphous Ca phosphate dissolved?
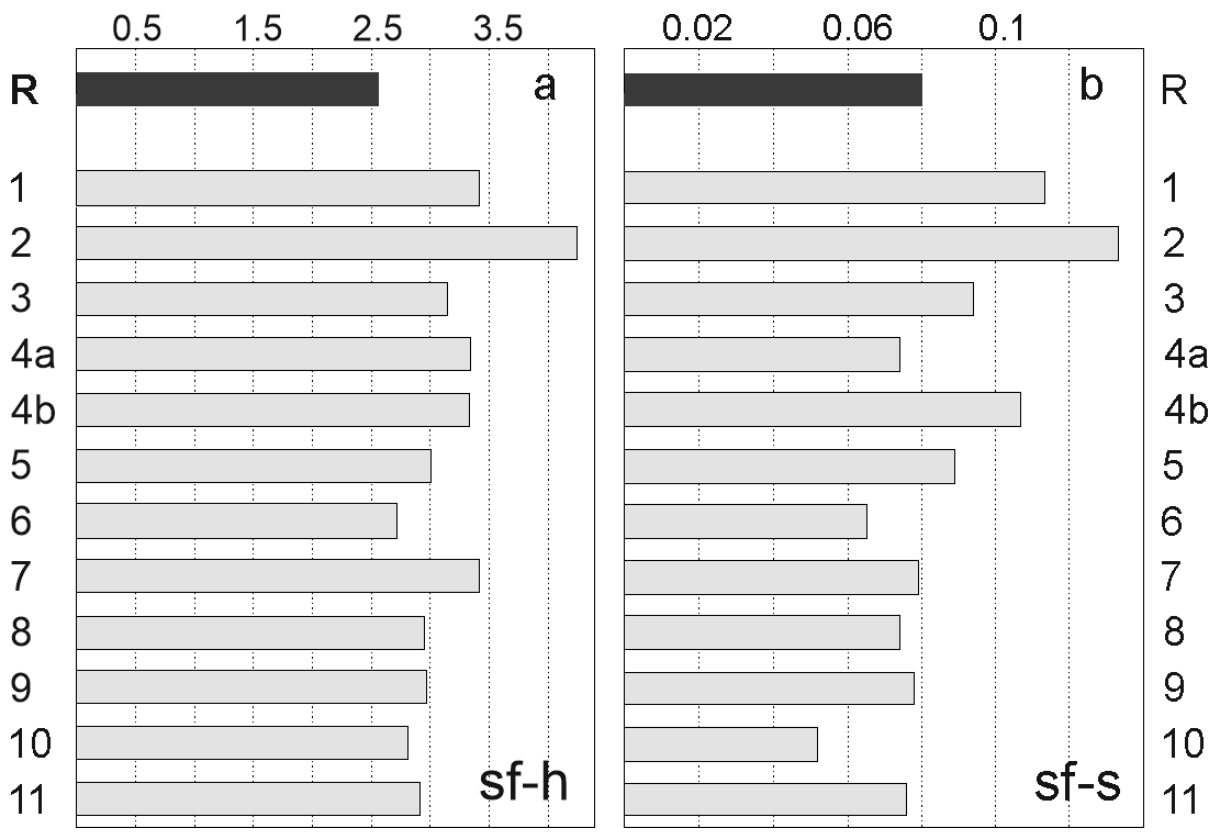

Figure 15. Crystallinity index (=splitting factor): (a) calculated from the band height (sf-h), (b) calculated from surface (sf-s) of the infrared spectra of long bones of Meriones. El Harhoura 2 cave (Morocco, late Pleistocene-middle Holocene). R: recent fresh bone.

The quality of the surface is important to quantify the elemental compositions using electron microprobes, and alumina is often used at the final stage of the preparative procedure. It is a trap, because round particles of alumina are very difficult to remove, 
even using hot water and detergent and an ultrasonic bath. So, the sample has a high Al content. The electron microprobe calculates the composition of the sample by comparing the intensities of characteristic X-rays from the sample material with intensities from standards. The sum of the studied elements must be $100 \%$. If $\mathrm{Al}$ content is artificially high because of the residual alumina, all other elements are artificially lowered. Thus, it is not enough to "remove" the Al content from the list of the analysed elements, because all other values are biased. Elemental compositions are used to learn the dietary patterns of fossil samples, to estimate the quality of the preservation, etc., so such biases are not welcome. Atomic force microscopy, X-Ray Absorption Near Edge Structure (XANES), Electron Back Scatter Diffraction (EBSD), Time-of-Flight Secondary Ion Mass Spectrometry (TOF-SIMS) and X-ray photoelectron spectroscopy (XPS), among other techniques, are also feasible on thin sections and/or polished surfaces. Another problem is the cleanliness of the sample. Some polishing products contain "oils". Obtaining the high vacuum often necessary in most analytical systems, a strong cleaning using detergent and ultrasonic bath is necessary. Sometimes it is not enough: TOF-SIMS is very sensitive to contaminants. Then, a very dilute acidic solution can be used to remove the striations due to the polishing procedures as well as dust.

A popular technique to see details of the inner structure of samples is tomography or CT-scan. It is said to be non-destructive [124]. Nevertheless, colour changes are observed in present-day and fossil teeth, indicative of chemical changes [125]. Similar alterations exist in invertebrate shells.

To estimate the molecular weights and the acidity of the organic matrices, liquid chromatography or electrophoresis can be used. Results depend on the column and eluent properties for liquid chromatography and on the nature and properties of the gels for electrophoresis. However, the main problem is that the molecular weight standards are globular proteins, although main proteins in mineralized tissues are fibrillar. Moreover, both techniques are sensitive for proteins (focussed on basic proteins) but not for sugars: refractometric detectors (for sugars) and staining procedures are not common. Another problem is inter-laboratory comparisons. Amino acid analyses on fossil bones are not rare and have been performed since the pioneering paper of Wyckoff [126]. Nevertheless, comparing the results is difficult because both the preparative and analytical procedures are diverse. The choice of the technique (high-performance liquid chromatography or gas chromatography) is important. Then, hydrolysis length and temperature play a role. The choice of the column and the derivatization (post- or pre-column) and detection mode (UV/visible or fluorescence detector) also induce different results. Similar problems are encountered with liquid chromatography for molecular weights or ion exchange: eluent, column and detector seem to provide "different" results. Such problems are not unique to analyses of proteins: they also exist for sugars and lipids [127]. The products of an acidic or a basic hydrolysis of the matrix extracted from a mineralized tissue are different.

Analytical systems are more and more precise and need only milligrams or micrograms of materials. Thus, even small samples are useful because several kinds of analyses are now possible [128]. The drawback is that diagenesis is not homogeneous within a single bone or tooth, so the statistical values of small amounts of materials are questionable. It is important to observe the structure of the analysed zones.

\subsection{Other Pitfalls}

It is not rare in recent papers to see that the oldest citation of an article is 1995: thanks to the internet, it is easy to collect papers without going to the library. The drawback is that some known features are ignored or rediscovered. On the contrary, some features commonly found and repeated in classical treatises are now known to be wrong. It is often said that enamel is not affected by diagenetic processes, but the outer layer of teeth extracted from present-day regurgitation pellets is missing (Figure 5a-c). Similarly, ancient teeth ("recent" from a geological point of view) are strongly etched (Figure 5d). In both cases, the morphology of the tooth was preserved, so that the taxa have been identified. 
This is not to say that all old papers are still pertinent. Since the works of Carnot [129], it has often been said that the fluorine contents of fossil bones and teeth are higher than those of present-day tissues. However, this is not a constant feature.

Exchanges between soil/sediment and bones or teeth are known, but the mechanisms are not yet deciphered. As demonstrated by Henderson et al. [130] fossil bones are not homogeneous from a chemical point of view. The intensity of the chemical changes is not related to the age of the fossil. In historical skeletons buried in lead coffins, the weight content of $\mathrm{Pb}$ reaches 37\% in the outer layer of the bones [131]. Bones and teeth of small mammals from the Late Miocene of Spain are enriched in mercury, but the strongest increase is in bone. In the apatite zones, the microstructure is preserved [132].

For present-day tissues, the main source of data comes from the medical literature, and human, bovid, mouse and rat are almost exclusively studied. Palaeontologists do not naturally read these journals, so our references are not always pertinent or updated. For example, it is said that collagen is only known in vertebrates, but collagen is also known in sponges, cephalopods and fungi. It is also said that collagen exists in dentine and bone, but collagen has also been evidenced in enamel $[76,133]$. Keratins, known only in fully organic tissues (hair, skin, etc.) have recently been detected in enamel [134]. Another problem is the quantity of a given protein through the life span of an individual. Osteocalcin levels reach a maximum shortly after birth and dropped in adult bovine bone. Osteonectin levels are stable but lower in woven bone than in lamellar bone matrix [135]. What about extinct species?

It is often said that acidic soil or sediment does not favour the preservation of bones and teeth. Bone is best preserved at $\mathrm{pH}=7.88[136,137]$, but $\mathrm{pH}$ is not the only factor to look for. Organic and mineral components are sensitive to an acidic environment, but the organic matrix is also sensitive to basic environments $(\mathrm{KOH}, \mathrm{NaOH}$ or $\mathrm{Na}$ hypochlorite are used to clean bones). Moreover, Berna et al. [138] (p. 867) have measured the ionic activity products at "steady state" conditions", and they "identify a recrystallization window between pH 7.6 and 8.1, which defines the conditions under which bone crystals dissolve and reprecipitate as a more insoluble form of carbonated hydroxyl apatite." These results are in accordance with the fact that when a fossil bone is demineralized, the residual component is not pure organic matrix $[19,139]$.

Because it is often difficult to separate enamel and dentine, most studies are dedicated to bones. Because collagen is the most abundant organic component, it is the most studied component. Moreover, techniques to study proteins are now diverse, cheap and automatic. This is not true for lipids and sugars. Thus, few data are available for these organics, even in present-day bones. From a geological point of view, this is a paradox because lipids are probably the most resistant $[84,127,140]$.

\subsection{New Techniques}

When they are successful in the search of new fossils, palaeontologists and archaeologists take care of their samples. They are carefully cleaned before being studied and stored. Multiple techniques are available, but nondestructive techniques are preferred. A popular nondestructive technique is tomography- $\mu \mathrm{CT}$ scan, but modifications have been noticed [126]. 3D reconstructions allow surficial marks or shapes to be isolated and differentiated for an easier comparison [26,141]. CTscan also allows researchers to reveal the inner structure of samples submitted to experimental diagenesis [142,143]. The current tendency is to combine the acquisition of several parameters on a single specimen. Ideally, acquisitions are simultaneous. CTscan is not the only technique used to collect 3D reconstructions. For FIB SEM (Focused Ion Beam Scanning Electron Microscopy) the ion beam etched the surface of the sample which is scanned for picture. For FIB SEM tomography, the process is repeated, and 3D reconstructions are done. Such data are mainly of interest for porous or heterogeneous samples [144,145]. Size and shapes of lacunae and canals in modern and fossil bone and teeth can be compared and inner modifications detected (Figure 16). Chemical composition of the FIB section is obtained by EDS analyses. 


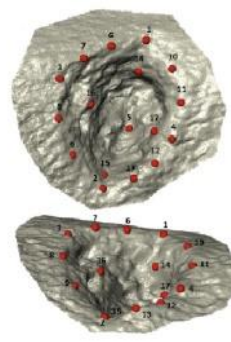

a

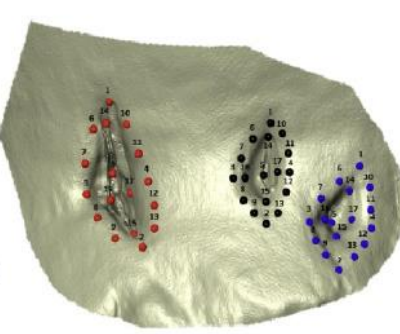

b
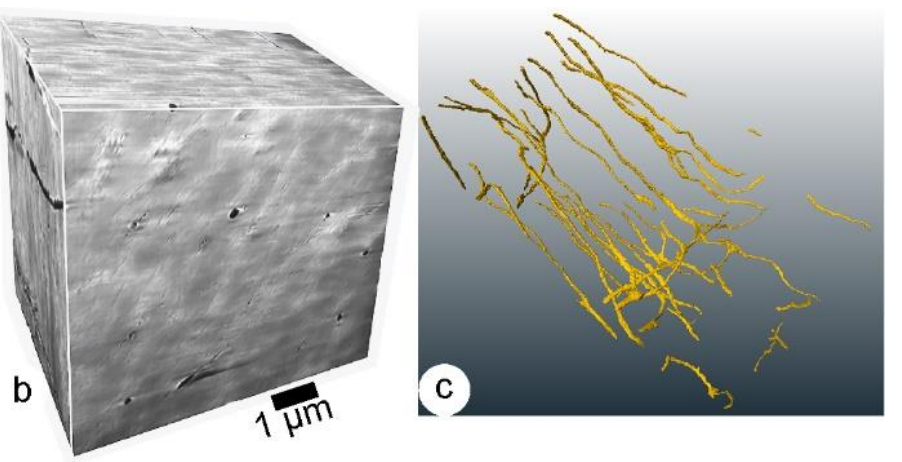

Figure 16. Computer tomography. (a) Crocodile pit on a long bone, from [141] with permission. (b) 3D FIB-SEM mineralized bone (credit E. Raguin). (c) Perspective rendering of the 3D segmented canaliculi network (credit E. Raguin)—(b,c): cortical bone pf a femur, domestic pig.

Among other in situ high-resolution techniques, it is also worth mentioning $\mu$-PIXE, NanoSIMS, ToF SIMS (Time of flight Secondary Ion Mass Spectrometry) and APT (Atom Probe Tomography), although they are rarely, if ever, used for fossils.

\section{Conclusions}

Although only Ca phosphate of vertebrates are taken into account, similar problems are encountered in Ca carbonates. As for Ca phosphates, the main mineral component is crystalline, although crystals are usually larger. For organisms with a silica skeleton, the story is different, with biogenic silica being amorphous.

The diagenetic modifications are diverse, depending on the structure and composition of the tissue, the cause of the death and the geological history. There are no relationships between the morphological aspect and preservation of a bone, or a tooth, and the quality of the preservation of the structure and composition. Moreover, a well-preserved microstructure appears not to be so-well preserved when looking at the nanostructure. To infer the quality of the preservation, a single criterion is not enough: the mineralogy can be good, but the elemental composition, the structure, etc. can be strongly modified. Structure can be preserved and elemental composition modified. Whatever the intensity of the diagenetic changes, the biological properties are altered, and the detected signals reflect the last event in the history of the sample. Therefore, looking for several parameters gives us data for a better understanding of the history of fossils. Most fossils are buried in sediments or soils, with no or moderate transport. Thus, temperature, $\mathrm{pH}$ and other environmental conditions recorded in fossils are not very different from those occurring during the life of the organisms. Therefore, they are plausible, but the unanswered question is whether they are actually those of the biological conditions. Finally, there are no direct relationships between the quality of the preservation and the geological age of the fossil. Effects of diagenesis on bone and teeth are so variable that they are not always predictable.

Funding: This research received no external funding.

Data Availability Statement: The author confirms that the data supporting the findings of this study are available within the article.

Acknowledgments: I am grateful to C. Denys (ISYEB), J.J. Jaeger (palevoprim), E. Buffetaut (ENS), E. Raguin (Max Planck Institute of colloids and interfaces) and A. Denis for their help.

Conflicts of Interest: The author declares no conflict of interest.

\section{References}

1. Bengtson, S. Origins and early evolution of predation. Paleont. Soc. Pap. 2002, 8, 289-318. [CrossRef]

2. Von Gumbel, C.W. Geognostische Besckreibung des Ostbayerischen Grenzgebirges oder des Bayerischen und Oberpfalzer Waldgebirges; Perthes: Gotha, Germany, 1868; 968p.

3. Efremov, I.A. Taphonomy: A new branch of paleontology. Pan Am. Geol. 1940, 74, 81-93. 
4. $\quad$ Lowenstam, H.A.; Weiner, S. On Biomineralization; Oxford University Press: Oxford, UK, 1989; 324p.

5. Anderson, P.S.L.; Westneat, M.W. A biomechanical model of feeding kinematics for Dunkleosteus terrelli (Arthrodira, Placodermi). Paleobiology 2009, 35, 251-269. [CrossRef]

6. Fourvel, J.B. Hyénidés Modernes et Fossiles d'Europe et d'Afrique: Taphonomie Comparée de Leurs Assemblages Osseux. Ph.D. Thesis, Toulouse Le Mirail Université, Toulouse, France; 597p. Available online: https://tel.archives-ouvertes.fr/tel-00830276 (accessed on 10 December 2021).

7. DeSantis, L.R.G. Dental microwear textures: Reconstructing diets of fossil mammals. Surf. Topogr. Metrol. Prop. $2016,4,023002$. [CrossRef]

8. Weissbrod, L.; Dayan, T.; Kaufman, D.; Weinstein-Evron, M. Micromammal taphonomy of el-Wad terrace, Mount Carmel, Israel: Distinguishing cultural from natural depositional agents in the Late Natufian. J. Archaeol. Sci. 2005, 32, 1-17. [CrossRef]

9. Matthews, T. Taphonomic characteristics of micromammals predated by small mammalian carnivores in South Africa: Applications to fossil accumulations. J. Taphon. 2006, 4, 143-161.

10. Matthews, T.; Rector, A.; Jacobs, Z.; Herries, A.I.R.; Marean, C.W. Environmental implications of micromammals accumulated close to MIS 6 to MIS5 transition at Pinnacle Point cave 9 (Mossel Bay, Wester, Cape Province, South Africa). Palaeogeogr. Palaeoclim. Palaeoecol. 2011, 302, 213-229. [CrossRef]

11. Fernández-Jalvo, Y.; Andrews, P. Atlas of Taphonomic Identifications: 1001+ Images of Fossil and Recent Mammal Bone Modification; Vertebrate Paleobiology and Paleoanthropology Series: Dordrecht, The Netherlands, 2016; pp. 1-359.

12. Weber, K.; Winkler, D.E.; Schulz-Kornas, E.; Kaiser, Y.M.; Tütken, T. The good, the bad and the ugly-A visual guide for common post-mortem wear patterns in vertebrate teeth. Palaeogeogr. Palaeoclim. Palaeoecol. 2021, 578, 110577. [CrossRef]

13. Epstein, A.G.; Epstein, J.B.; Harris, L.D. Conodont color alteration: An index to organic metamorphism. Geol. Surv. Prof. Pap. 1977, 995, 1-27.

14. López-González, F.; Grandal-d'Anglade, A.; Vidal-Romaní, J.R. Deciphering bone depositional sequences in caves through the study of manganese coatings. J. Archaeol. Sci. 2006, 33, 707-717. [CrossRef]

15. Monge, G.; Carretero, M.I.; Pozo, M.; Barroso, C. Mineralogical changes in fossil bones from Cueva del Angel, Spain: Archaeological implications and occurrence of whitlokite. J. Archaeol. Sci. 2014, 46, 6-15. [CrossRef]

16. Franchet, L. La coloration des os dans le sol. Le bouillage des cadavres au Moyen Age, l'incinération et ses phénomènes. Rev. Sci. 1933, 483-495, 520-532.

17. Franchet, L. Coloration of fossil bones. Nature 1934, 33, 60.

18. Dauphin, Y.; Nespoulet, R.; Stoetzel, E.; el Haijraoui, M.A.; Denys, C. Can colour be used as a proxy for paleoenvironmental reconstructions based on archaeological bones? El Harhoura 2 (Morocco) case study. J. Taphon. 2012, 10, 69-84.

19. Dauphin, Y.; Lange-Badré, D. Evaluation de la conservation de l'os fossile: Intégration des différents niveaux d'observation. Paläont. Zeit. 2000, 74, 441-457. [CrossRef]

20. Rensberger, J.M.; Krentz, H.B. Microscopic effects of predator digestion on the surfaces of bones and teeth. Scanning Microsc. 1988, 2,30 .

21. Denys, C.; Kowalski, K.; Dauphin, Y. Mechanical and chemical alterations of skeletal tissues in a recent Saharian accumulation of faeces from Vulpes rueppelli (Carnivora, Mammalia). Acta Zool. Cracov. 1992, 35, 265-283.

22. Denys, C.; Fernandez-Jalvo, Y.; Dauphin, Y. Experimental taphonomy: Preliminary results of the digestion of micromammal bones in the laboratory. C. R. Acad. Sci. 1995, 321, 803-809.

23. Bell, L.S. Forensic Microscopy for Skeletal Tissues: Methods and Protocols; Methods in Molecular Biology; Humana Press: Totowa, NJ, USA, 2012; Volume 915, pp. 1-269.

24. Turner-Walker, G.; Syversen, U. Quantifying histological changes in archaeological bones using BSE-SEM image analysis. Archaeometry 2002, 44, 461-468. [CrossRef]

25. Crouzier, L.; Delvallée, A.; Ducourtieux, S.; Devoille, L.; Noircler, G.; Ulysse, C.; Taché, O.; Barruet, E.; Tromas, C.; Feltin, N Development of a new hybrid approach combining AFM and SEM for the nanoparticle dimensional metrology. Beilstein J. Nanotechnol. 2019, 10, 1523-1536. [CrossRef]

26. Kral, A.G.; Ziegler, A.; Tütken, T.; Geisler, T. Experimental aqueous alteration of cortical bone microarchitecture analyzed by quantitative micro-computed tomography. Front. Earth Sci. 2021, 9, 609496. [CrossRef]

27. Andrews, P. Owls, Caves and Fossils; Natural History Museum Publications: London, UK, 1990; pp. 1-231.

28. Leprince, P.; Dandrifosse, G.; Schoffeniels, E. The digestive enzymes and acidity of the pellets regurgitated by raptors. Biochem. Syst. Ecol. 1979, 7, 223-227. [CrossRef]

29. Turner-Walker, G.; Jans, M. Reconstructing taphonomic histories using histological analysis. Palaeogeogr. Palaeoclim. Palaeoecol. 2008, 266, 227-235. [CrossRef]

30. Weiner, S.; Traub, W. Bone structure: From angstroms to microns. FASEB 1992, 6, 879-885. [CrossRef]

31. Schweitzer, M.H.; Zheng, W.; Organ, C.L.; Avci, R.; Suo, Z.; Freimark, L.M.; Lebleu, V.S.; Duncan, M.B.; Vander Heiden, M.G.; Neveu, J.M.; et al. Biomolecular characterization and protein sequences of the Campanian hadrosaur B. canadensis. Science 2009, 324, 626-631. [CrossRef] [PubMed]

32. Ullmann, P.V.; Voegele, K.K.; Grandstaff, D.E.; Ash, R.D.; Zheng, W.; Schroeter, E.R.; Schweitzer, M.H.; Lacovara, K.J. Molecular tests support the viability of rare earth elements as proxies for fossil biomolecule preservation. Sci. Rep. 2020, 10, 15566. [CrossRef] 
33. Dauphin, Y.; Montuelle, S.; Quantin, C.; Massard, P. Estimating the preservation of tooth structures: Towards a new scale of observation. J. Taphon. 2007, 5, 43-56.

34. Skinner, H.C.W. Biominerals. Mineral. Mag. 2005, 69, 621-641. [CrossRef]

35. Dauphin, Y.; Massard, P. Diagenèse des os de rongeurs fossiles d'El Harhoura 2 (Maroc): Microstructure versus composition globale. Trav. Inst. Sci. 2015, 8, 31-42.

36. Greiner, M.; Rodríguez-Navarro, A.; Heinig, M.F.; Mayer, K.; Kocsis, B.; Göhring, A.; Toncala, A.; Grupe, G.; Schmahl, W.W. Bone incineration: An experimental study on mineral structure, colour and crystalline state. J. Archaeol. Sci. Rep. 2019, 25, 507-518. [CrossRef]

37. Mac Connell, D. Apatite_-Its Crystal Chemistry, Mineralogy, Utilization and Biological Occurrence; Springer: Wien, Austria, 1973; pp. 1-111.

38. Elliott, J.C. Infrared and Raman spectroscopy of calcified tissues. In Methods of Calcified Tissues Preparation; Dickson, G.R., Ed.; Elsevier: Amsterdam, The Netherlands, 1984; pp. 413-434.

39. Pan, Y.; Fleet, M.E. Compositions of the apatite-group minerals: Substitution mechanisms and controlling factors. Rev. Mineral. Geochem. 2002, 48, 13-49. [CrossRef]

40. Wopenka, B.; Pasteris, J. A mineralogical perspective on the apatite in bone. Mater. Sci. Engin. 2005, C25, 131-143. [CrossRef]

41. Labs-Hochstein, J.; MacFadden, B.J. Quantification of diagenesis in cenozoic sharks: Elemental and mineralogical changes. Geochim. Cosmochim. Acta 2006, 70, 4921-4932. [CrossRef]

42. Legeros, R.; Ben-Nissan, B. Introduction to synthetic and biological apatites. In Advances in Calcium Phosphate Biomaterials; Ben Nissan, B., Ed.; Springer Series in Biomaterials Science and Engineering: Heidelberg, Germany, 2014; Volume 2, Chapter 1. [CrossRef]

43. Shemesh, A. Crystallinity and diagenesis of sedimentary apatites. Geochim. Cosmochim. Acta 1990, 54, 2422-2428. [CrossRef]

44. Stiner, M.C.; Kuhn, S.L.; Surovell, T.A.; Goldberg, P.; Meignen, L.; Weiner, S.; Bar-Yosef, O. Bone preservation in Hayonim cave (Israel): A macroscopic and mineralogical study. J. Archaeol. Sci. 2001, 28, 643-659. [CrossRef]

45. Farre, B.; Massard, P.; Nouet, J.; Dauphin, Y. Preservation of rodent bones from El Harhoura 2 cave (Morocco, Neolithic-Middle Palaeolithic): Microstructure, mineralogy, crystallinity and composition. J. Afr. Earth Sci. 2014, 92, 1-13. [CrossRef]

46. Suzuki, M. Studies on the physicochemical nature of hard tissue. Infrared, N.M.R., X-ray diffraction investigation of hydroxylradical, crystalline water and carbonate substitution in biological apatites. In Physicochimie et Cristallographie des Apatites D'intérêt Biologique; CNRS: Paris, France; pp. 77-83.

47. Stutman, J.M.; Termine, J.D.; Posner, A.S. Vibrational spectra and structure of the phosphate ion in some calcium phosphates. Trans. N.Y. Acad. Sci. 1965, 27, 669-675. [CrossRef]

48. Adamiano, A.; Fabbri, D.; Falini, G.; Belcastro, G. A complementary approach using analytical pyrolysis to evaluate collagen degradation and mineral fossilization in archaeological bones: The case study of Vicenne-Campochiaro necropolis (Italy). J. Anal. Appl. Pyrolysis 2013, 100, 173-180. [CrossRef]

49. Termine, J.D.; Posner, A.S. Infra-red determination of the percentage of crystallinity in apatitic calcium phosphates. Nature 1966, 211, 268-270. [CrossRef]

50. Weiner, S.; Bar-Yosef, O. States of preservation of bones from prehistoric sites in the Near East: A survey. J. Archaeol. Sci. 1990, 17, 187-196. [CrossRef]

51. Sillen, A. Biogenic and diagenetic Sr/Ca in Plio-Pleistocene fossils of the Omo Shungura formation. Paleobiology 1986, 12, 311-323. [CrossRef]

52. Legeros, R.Z.; Trautz, O.R.; Klein, E.; Legeros, J.P. Two types of carbonate substitution in the apatite structure. Experientia 1969, 25, 5-7. [CrossRef] [PubMed]

53. Rey, C.; Renugopalaskrishnan, V.; Collins, B.; Glimcher, M.J. Fourier Transform infrared spectroscopic study of the carbonate ions in bone mineral during aging. Calc. Tissue Intern. 1991, 49, 251-258. [CrossRef] [PubMed]

54. Botha, J.; Lee-Thorp, J.; Sponheimer, M. An examination of triassic cynodont tooth enamel chemistry using Fourier Transform Infrared spectroscopy. Calc. Tissue Intern. 2004, 74, 162-169. [CrossRef] [PubMed]

55. Boskey, A.L. Mineralization of bones and teeth. Elements 2007, 3, 385-391. [CrossRef]

56. Boskey, A.; Camacho, N.P. FT-IR imaging of native and tissue-engineered bone and cartilage. Biomaterials 2007, 28, 2465-2478. [CrossRef]

57. Kazanci, M.; Roschger, P.; Paschalis, E.P.; Klaushofer, K.; Fratzl, P. Bone osteonal tissues by Raman spectral imaging: Orientationcomposition. J. Struct. Biol. 2006, 156, 489-496. [CrossRef]

58. Gamsjaeger, S.; Masic, A.; Roschger, P.; Kazanci, M.; Dunlop, J.W.C.; Klaushofer, K.; Paschalis, E.P.; Fratzl, P. Cortical bone composition and orientation as a function of animal and tissue age in mice by Raman spectroscopy. Bone 2010, 47, 392-399. [CrossRef]

59. Amarie, S.; Zaslansky, P.; Kajihara, Y.; Griesshaber, E.; Schmahl, W.W.; Keilmann, F. Nano-FTIR chemical mapping of minerals in biological materials. Beilstein J. Nanotech. 2012, 3, 312-323. [CrossRef]

60. Dauphin, Y.; Castillo-Michel, H.; Farre, B.; Mataame, A.; Rbii, K.; Rihane, A.; Stoetzel, E.; Denys, C. Identifying predation on rodent teeth through structure and composition: A case from Morocco. Micron 2015, 75, 34-44. [CrossRef]

61. Dauphin, Y.; Denis, A. Modifications de structure et de composition des biominéraux phosphatés des vertébrés. In TaphonomieS; Brugal, J.P., Ed.; Archives Contemporaines: Paris, France, 2017; pp. 24-43. 
62. Woess, C.; Unterberger, S.H.; Roider, C.; RitschMarte, M.; Pemberger, N.; Cemper-Kiesslich, J.; Hatzer-Grubwieser, P.; Parson, W.; Pallua, J.D. Assessing various Infrared (IR) microscopic imaging techniques for post-mortem interval evaluation of human skeletal remains. PLoS ONE 2017, 12, e0174552. [CrossRef] [PubMed]

63. Reisz, R.R.; Huang, T.D.; Roberts, E.M.; Peng, S.R.; Sullivan, C.; Stein, K.; LeBlanc, A.R.H.; Shieh, D.B.; Chang, R.S.; Chiang, C.C.; et al. Embryology of Early Jurassic dinosaur from China with evidence of preserved organic remains. Nature 2013, 496, 210-214. [CrossRef] [PubMed]

64. Mendelsohn, R.; Paschalis, E.P.; Sherman, P.J.; Boskey, A.L. IR microscopic imaging of pathological states and fracture healing of bone. Appl. Spectr. 2000, 54, 1183-1191. [CrossRef]

65. Parker, R.B.; Toots, H. Minor elements in fossil bone. Geol. Soc. Amer. Bull. 1970, 81, 925-932. [CrossRef]

66. Dauphin, Y.; Williams, C.T.; Andrews, P.; Denys, C.; Fernandez-Jalvo, Y. Diagenetic alterations of micromammal fossil bones from Olduvai Bed I of the Lower Pleistocene sequence at Olduvai gorge, Tanzania. J. Sedim. Res. 1999, 69, 612-621. [CrossRef]

67. Fowler, B.O. Infrared studies of apatites 1. vibrational assignments for calcium, strontium and barium hydroxyapatites utilizing isotopic substitution. Inorg. Chem. 1974, 13, 194-207. [CrossRef]

68. Brophy, G.P.; Nash, J.T. Compositional, infrared, and X-ray analysis of fossil bone. Amer. Mineral. 1968, 53, 445-454.

69. Sakae, T.; Mishima, H.; Kozawa, Y. Proboscidea fossil teeth suggest the evolution of enamel crystals. In Mechanisms and Phylogeny of Mineralization in Biological Systems; Suga, S.H., Nakahara, H., Eds.; Springer: Tokyo, Japan, 1991; pp. $477-481$.

70. El Feki, H.; Rey, C.; Vignoles, C.M. Carbonate ions in apatites: Infrared investigations in the $44 \mathrm{CO}_{3}$ domain. Calc. Tissue Intern. 1991, 49, 269-274. [CrossRef]

71. Dauphin, Y. Potential of the diffuse reflectance infrared Fourier transform (DRIFT) method in paleontological studies of bones Appl. Spectr. 1993, 47, 52-55. [CrossRef]

72. Dauphin, Y. Spectrométrie infrarouge (DRIFT) des os de rongeurs fossiles de Tighenif (Pleistocène, Algérie). Paläont. Z. 1993, 67, 377-395. [CrossRef]

73. Thomas, D.B.; Fordyce, R.E.; Frew, R.D.; Gordon, K.C. A rapid, non-destructive method of detecting diagenetic alteration in fossil bone using Raman spectroscopy. J. Raman Spectr. 2007, 38, 1533-1537. [CrossRef]

74. King, T.; Andrews, P.; Basak, B. Effect of taphonomic processes on dental microwear. Amer. J. Phys. Anthr. 1999, 108, 359-373. [CrossRef]

75. Mishima, H.; Kakei, M.; Sasagawa, I.; Miake, Y. Nature of apatite crystals in the tooth of Eusthenopteron from Devonian. J. Hard Tissue Biol. 2017, 26, 399-404. [CrossRef]

76. Açil, Y.; Mobasseri, A.E.; Warnke, P.H.; Terheyden, H.; Wiltfang, J.; Springer, I. Detection of mature collagen in human dental enamel. Calc.Tissue Intern. 2005, 76, 121-126. [CrossRef]

77. Van der Rest, M.; Garrone, R. Collagen family of proteins. FASEB J. 1991, 5, 2814-2823. [CrossRef]

78. Ricard-Blum, S. The collagen family. Cold Spring Harb. Perspect. Biol. 2011, 3, a004978. [CrossRef]

79. Easteo, J.E. The amino acid composition of Mammalia, collagen and gelatin. Biochem J. 1955, 61, 589-600. [CrossRef]

80. Pawlicki, R. Topochemical localization of lipids in dinosaur bone by means of Sudan B black. Acta Histochem. 1977, 59, 40-46. [CrossRef]

81. Pawlicki, R. Histochemical reactions for mucopolysaccharides in the dinosaur bone studies on Epon- and methacrylate-embedded semithin sections as well as on isolated osteocytes and ground sections of bone. Acta Histochem. 1977, 58, 75-78. [CrossRef]

82. Ulrich, M.M.W.; Perizonius, W.R.K.; Spoor, C.F.; Sandberg, P.; Vermeer, C. Extraction of osteocalcin from fossil bones and teeth. Biochem. Biophys. Res. Com. 1987, 149, 712-719. [CrossRef]

83. Muyzer, G.; Sandberg, P.; Knapen, M.H.J.; Vermeer, C.; Collins, M.; Westbroek, P. Preservation of the bone protein osteocalcin in dinosaurs. Geology 1992, 20, 871-874. [CrossRef]

84. Evershed, R.P.; Turner-Walker, G.; Hedges, R.E.M.; Tuross, N.; Leyden, A. Preliminary results for the analysis of lipids in ancient bone. J. Archaeol. Sci. 1995, 22, 277-290. [CrossRef]

85. Poinar, H.N.; Stankiewicz, B.A. Protein preservation and DNA retrieval from ancient tissues. Proc. Natl. Acad. Sci. USA 1999, 96 , 8426-8431. [CrossRef] [PubMed]

86. Dobberstein, R.C.; Collins, M.J.; Craig, O.E.; Taylor, G.; Penkman, K.E.H.; Ritz-Timme, S.R. Archaeological collagen: Why worry about collagen diagenesis? Archaeol. Anthropol. Sci. 2009, 1, 31-42. [CrossRef]

87. Wiens, J.J.; Kuczynski, C.A.; Townsend, T.; Reeder, T.W.; Mulcahy, D.G.; Sites, J.W., Jr. Combining phylogenomics and fossils in higher-level squamate reptile phylogeny: Molecular data change the placement of fossil taxa. System. Biol. 2010, 59, 674-688. [CrossRef]

88. Woodward, S.R.; Weyand, N.J.; Bunnell, M. DNA sequence from Cretaceous period bone fragments. Science 1994, 266, 1229-1232. [CrossRef]

89. Zischler, H.; Höss, M.; Handt, O.; von Haeseler, A.; van der Kuyl, A.C.; Goudsmit, J. Detecting dinosaur DNA. Science 1995, 268, 1192-1193. [CrossRef]

90. Haouchar, D.; Haile, J.; McDowell, M.C.; Murray, D.C.; White, N.E.; Allcock, R.J.N.; Phillips, M.J.; Prideaux, G.J.; Bunce, M. Thorough assessment of DNA preservation from fossil bone and sediments excavated from a late Pleistocene-Holocene cave deposit on Kangaroo Island, South Australia. Quater. Sci. Rev. 2014, 84, 56-64. [CrossRef] 
91. Ferrari., G.; Cuevas, A.; Gondek-Wyrozemsha, A.T.; Ballantyne, R.; Kersten, O.; Palsdottir, A.H.; van der Jagt, I.; Hufthammer, A.K.; Ystgaard, I.; Wickler, S.; et al. The preservation of ancient DNA in archaeological fish bone. J. Archaeol. Sci. 2021, 126, 105317. [CrossRef]

92. Korvenkontio, V.A. Mikroskopische Untersuchungen an Nagerincisiven unter Hinweis auf die Schmelzstruktur der Backenzähne. Ann. Zool. Soc. Zool. Bot. Fenn. Vanamo 1934, 2, 1-274.

93. Peyer, B. Comparative Odontology; Zangerl, T., Translator; University Chicago Press: Chicago, IL, USA, 1968 ; pp. 1-458.

94. von Koenigswald, W.; Sander, P.M. Tooth Enamel Microstructure; Balkema, A.A., Ed.; CRC Press: Rotterdam, The Netherlands, 1997; pp. 1-280.

95. Stahl, P.W. The recovery and interpretation of microvertebrate bone assemblages from archaeological contexts. J. Archaeol. Meth. Theory 1996, 3, 31-75. [CrossRef]

96. Dodson, P.; Wexlar, D. Taphonomic investigations of owl pellets. Paleobiology 1979, 5, 275-284. [CrossRef]

97. Voorhies, M. Taphonomy and population dynamics of an early Pleistocene vertebrate fauna Knox County Nebraska. In Contributions to Geology; University Wyoming Press: Laramie, WY, USA, Special Paper 1.

98. Domínguez-Rodrigo, M. Critical review of the MNI (minimum number of individuals) as a zooarchaeological unit of quantification. Archaeol. Anthropol. Sci. 2012, 4, 47-59. [CrossRef]

99. Bockenski, Z.M.; Tomek, T. Preservation of bird bones: Erosion versus digestion by owls. Intern. J. Osteoarch. 1997, 7, 372-387. [CrossRef]

100. Fernández-Jalvo, Y.; Andrews, P.; Sevilla, P.; Requejo, V. Digestion vs. abrasion features in rodent bones. Lethaia 2014, 47, 323-336. [CrossRef]

101. Denys, C. Le gisement Pliocène de Laetoli (Tanzanie, Afrique de l’Est): Analyse taphonomique des assemblages de microvertébrés. Palaeontographica 1986, A194, 69-98.

102. Czaplewski, N.J. An owl-pellet accumulation of small Pliocene vertebrates from the Verde Formation, Arizona, USA. Palaeont. Electr. 2011, 14, 1-33.

103. Arriaza, M.C.; Domínguez-Rodrigo, M.; Yravedra, J.; Baquedano, E. Lions as bone accumulators? Paleontological and ecological implications of a modern bone assemblage from Olduvai Gorge. PLoS ONE 2016, 11, e0153797. [CrossRef]

104. Andrews, P.; Nesbit Evans, E.M. Small mammal bone accumulations produced by mammalian carnivores. Paleobiology 1983, 9 , 289-307. [CrossRef]

105. DeNiro, M.J.; Weiner, S. Chemical, enzymatic and spectroscopic characterization of "collagen" and other organic fractions from prehistoric bones. Geochim. Cosmochim. Acta 1988, 52, 2197-2206. [CrossRef]

106. Collins, M.J.; Nielsen-Marsh, C.M.; Hiller, J.; Smith, C.I.; Roberts, J.P. The survival of organic matter in bone: A review. Archaeometry 2002, 44, 383-394. [CrossRef]

107. Turner-Walker, G. The chemical and microbial degradation of bones and teeth. In Advances in Human Palaeopathology; Pinhasi, R., Mays, S., Eds.; Wiley \& Sons: Chichester, UK, 2008; pp. 3-30.

108. Trueman, C.; Behrensmeyer, A.; Tuross, N.; Weiner, S. Mineralogical and compositional changes in bones exposed on soil surfaces in Amboseli National Park, Kenya: Diagenetic mechanisms and the role of sediment pore fluids. J. Archaeol. Sci. 2004, 31, 721-739. [CrossRef]

109. Janssens, K.; Vincze, L.; Vekemans, B.; Williams, C.T.; Radtke, M.; Haller, M.; Knöchel, A. The non-destructive determination of REE in fossilized bone using synchrotron radiation induced K-line X-ray microfluorescence analysis. Fresenius J. Anal. Chem. 1999, 363, 413-420. [CrossRef]

110. Denys, C.; Williams, C.T.; Dauphin, Y.; Andrews, P.; Fernandez-Jalvo, Y. Diagenetical changes in Pleistocene small mammal bones from Olduvai Bed I. Palaeogeogr. Palaeoclim. Palaeoecol. 1996, 126, 121-134. [CrossRef]

111. Williams, C.T. Alteration of chemical composition of fossil bones by soil processes and groundwater. In Trace Elements in Environmental History; Grupe, G., Herrmann, B., Eds.; Springer: Berlin, Germany, 1988; pp. 27-40.

112. Rosling, A.; Suttle, K.B.; Johnasson, E.; Van Hees, P.A.W.; Banfield, J.F. Phosphorous availability influences the dissolution of apatite by soil fungi. Geobiology 2007, 5, 265-280. [CrossRef]

113. Smits, M.M.; Bonneville, S.; Benning, L.G.; Banwart, S.A.; Leake, J.R. Plant-driven weathering of apatite-The role of an ectomycorrhizal fungus. Geobiology 2013, 10, 445-456. [CrossRef]

114. Bada, J.L.; Wang, X.S.; Hamilton, H. Preservation of key biomolecules in the fossil record: Current knowledge and future challenges. Philos. Trans. R. Soc. London. Ser. B Biol. Sci. 1999, 354, 77-86. [CrossRef]

115. Holmes, K.M.; Robson Brown, K.A.; Oates, W.P.; Collins, M.J. Assessing the distribution of African Palaeolithic sites: A predictive model of collagen degradation. J. Archaeol. Sci. 2005, 32, 157-166. [CrossRef]

116. Bodzioch, A. Idealized model of mineral infillings in bones of fossil freshwater animals, on the example of Late Triassic Metoposaurs from Krasiejów (Poland). Austin J. Earth Sci. 2015, 2, 1-6.

117. Hinz, E.A.; Kohn, M.J. The effect of tissue structure and soil chemistry on trace element uptake in fossils. Geochim. Cosmochim. Acta 2010, 74, 3213-3231. [CrossRef]

118. Dauphin, Y.; Castillo-Michel, H.; Denys, C.; El Hajiraoui, M.A.; Nespoulet, R.; Stoetzel, E. Diagenetic alterations of Meriones incisors (Rodentia) of El Harhoura 2 cave, Morocco (Late Pleistocene-Middle Hococene). PalZ 2018, 92, 163-177. [CrossRef]

119. Rosin, Z.M.; Kwiecinski, Z. Digestibility of prey by the White Strok (Ciconia ciconia) under experimental conditions. Ornis Fenn. 2011, 88, 40-50. 
120. Cummings, J.H.; Duke, G.E.; Jegers, A.A. Corrosion of bone by solutions simulating raptor gastric juice. Raptor Res. 1976, 10, $55-57$.

121. Keenan, S.W.; Engel, A.S. Early diagenesis and recrystallization of bone. Geochim. Cosmochim. Acta 2017, 196, 209-233. [CrossRef]

122. Massard, P.; Dauphin, Y. Sols, sédiments et biominéraux phosphatés: Expériences in vitro. In TaphonomieS; Brugal, J.P., Ed.; Archives Contemporaines: Paris, France, 2017; pp. 89-106.

123. Lev, M.; Weinstein-Evron, M.; Yeshurun, R. Squamate bone taphonomy: A new experimental framework and its application to the Natufian zooarchaeological record. Scient. Rep. 2020, 10, 9373. [CrossRef] [PubMed]

124. Schulmerich, M.V.; Cole, J.H.; Dooley, K.A.; Morris, M.D.; Kreider, J.M.; Goldstein, S.A.; Srinivasan, S.; Pogue, B.W. Noninvasive Raman tomographic imaging of canine bone tissue. J. Biomed. Opt. 2008, 13, 020506. [CrossRef] [PubMed]

125. Richards, G.D.; Jabbour, R.S.; Horton, C.F.; Ibarra, C.L.; MacDowell, A.A. Color Changes in modern and fossil teeth induced by synchrotron microtomography. Amer. J. Phys. Anthr. 2012, 149, 172-180. [CrossRef]

126. Wyckoff, R.W.G. Sur la composition de quelques protéines dinosauriennes. C. R. Hebd. Séances Acad. Sci. 1969, $269,1489-1491$.

127. Whelton, H.L.; Hammann, S.; Cramp, L.J.E.; Dunne, J.; Roffet-Salque, M.; Evershed, R.P. A call for cautíon in the analysis of lipids and other small biomolecules from archaeological contexts. J. Archaeol. Sci. 2021, 132, 105397. [CrossRef]

128. Schweitzer, M.H.; Avci, R.; Collier, T.; Goodwind, M.B. Microscopic, chemical and molecular methods for examining fossil preservation. C. R. Palevol. 2008, 7, 159-184. [CrossRef]

129. Carnot, A. Recherche du fluor dans les os modernes et les os fossiles. C. R. Hebd. Séances Acad. Sci. 1982, 114, 1189.

130. Henderson, P.; Marlow, C.A.; Molleson, T.I.; Williams, C.T. Patterns of chemical change during bone fossilization. Nature 1983, 306, 358-360. [CrossRef]

131. Molleson, T.I.; Williams, C.T.; Cressey, G.; Din, V.K. Radiographically opaque bones from lead-lined coffins at Christ Church, Spitalfields, London; an extreme example of bone diagenesis. Bull. Soc. Geol. Fr. 1998, 169, 425-432.

132. Garcia-Alix, A.; Minwer-Barakat, R.; Martin Suarez, E.; Freudenthal, M.; Delgado Huertas, A. Cinnabar mineralization in fossil small mammal remains as a consequence of diagenetic processes. Lethaia 2013, 46, 1-6. [CrossRef]

133. Asaka, T.; Akiyama, M.; Domon, T.; Nishie, W.; Natsuga, K.; Fujita, Y.; Abe, R.; Kitagawa, Y.; Shimizu, H. Type XVII Collagen is a key player in tooth enamel formation. Amer. J. Pathol. 2009, 174, 91-100. [CrossRef] [PubMed]

134. Duverger, O.; Beniash, E.; Morasso, M.I. Keratins as components of the enamel organic matrix. Matrix Biol. 2016, 52-54, 260-265. [CrossRef] [PubMed]

135. Conn, K.M.; Termine, J.D. Matrix protein profiles in calf bone development. Bone 1985, 6, 33-36. [CrossRef]

136. Homburg, J.A. Archeology in relation to soils. In Encyclopedia of Soils in the Environment; Hillel, D., Rosenweig, C., Powlson, D., Scow, K., Singer, M., Sparks, D., Eds.; Elsevier: Oxford, UK, 2005; pp. 95-102.

137. Retallack, G.J. Soils of the Past-An Introduction to Paleopedology; Springer Science \& Business Media: Berlin/Heidelberg, Germany, 2018; Volume 212, p. 520.

138. Berna, F.; Matthews, A.; Weiner, S. Solubilities of bone mineral from archaeological sites: The recrystallization window. J. Archaeol. Sci. 2004, 31, 867-882. [CrossRef]

139. Montgelard, C.; Buchy, M.C.; Gautret, P.; Dauphin, Y. Biogeochemical characterization of ichthyosaur bones from Holzmaden (Germany, Lias). Bull. Soc. Géol. Fr. 1997, 168, 759-766.

140. Colleary, C.; Lamadrid, H.M.; O’Reilly, S.S.; Dolocan, A.; Nesbitt, S.J. Molecular preservation in mammoth bone and variation based on burial environment. Scient. Rep. 2021, 11, 2662. [CrossRef]

141. Aramendi, J.; Maté-González, M.A.; Yravedra, J.; Cruz Ortega, M.; Arriaza, M.C.; González-Aguilera, D.; Baquedano, E.; Domínguez-Rodrigo, M. Discerning carnivore agency through the three-dimensional study of tooth pits: Revisiting crocodile feeding behaviour at FLK- Zinj and FLK NN3 (Olduvai Gorge, Tanzania). Palaeogeogr. Palaeoclim. Palaeoecol. 2017, 488, 93-102. [CrossRef]

142. Georgiadis, M.; Guizar-Sicairos, M.; Gschwend, O.; Hangartner, P.; Bunk, O.; Müller, R.; Schneider, P. Ultrastructure organization of human trabeculae assessed by 3D sSAXS and relation to bone microarchitecture. PLoS ONE 2016, 11, e0159838. [CrossRef] [PubMed]

143. Lacel, A.; Wojtkow, M.; Tomanis, M.; Spiak, Z.; Graczyk, S.; Pezowicz, C. The influence of a standardized experimental environment on early diagenetic changes to animal bone. Geoarchaeology 2021, 36, 755-767. [CrossRef]

144. Raguin, E.; Rechav, K.; Brumfeld, V.; Shahar, R.; Weiner, S. Unique three-dimensional structure of a fish pharyngeal jaw subjected to unusually high mechanical loads. J. Struct. Biol. 2020, 211, 107530. [CrossRef] [PubMed]

145. Raguin, E.; Rechav, K.; Shahar, R.; Weiner, S. Focused ion beam-SEM 3D analysis of mineralized osteonal bone: Lamellae and cement sheath structures. Acta Biomat. 2021, 121, 497-513. [CrossRef] 